\title{
核融合エネルギーシステムの将来展望
}

\section{Prospects of Fusion Energy System}

神前康次, 関 泰, 本島 修, 百田弘,三間图興, 北川米喜, 中井貞雄, 浅見直人, 中島秀紀, 永嶺謙忠

（1992年 11 月 18 日 受理）

21 世紀のエネルギーシステムとして大きい期待を集めている核融合エネルギーは現在，DT 燃料卜 カマクを主路線として研究開発が進められ，トカマク装置においてゼロ出力条件をほほ満たすプラズ マ閉じ込めに成功している。しかし，核融合エネルギーは他に様々な発生扔よび利用形態が考えられ る。現在のところ実用化までには多くの課題があるものの, 将来実用化されれば人類に大きく貢献し うると考えられている核融合エネルギーシステムについて，現在の研究状況ならびに実現のための研 究課題を整理することは, 今後の核融合エネルギ一のみならず，原子力全体の研究開発の将来展望を つかむ上で重要な意味を持つと考えられるので，それぞれの専門家の方々に解説して頂いた。

(担当編集委員・横内洋二,大西正視)
I 、はじめに
II .トカマク型核骶合炉
VI. 核融合-核分裂ハイブリッド炉
III. ヘリカル型核蟨合炉
VI. 核融合ロケット
IV. $\mathrm{D}^{-3} \mathrm{HeFRC}$ 核融合炉
VIIJ.ミュオン触媒核融合, 常温核融合など
V. 慣性核融合炉

\section{I 、はじめに}

財未来工学研究所 神前康 次

\section{1. 核融合の夢と現実}

一その歴史を振り返って

核融合は宇宙のエネルギー源であり，地上での制 御核融合の実現は人類の夢である。この夢と現実の 迫間で，核融合研究開発は幾多の困難に直面するこ とになる。その歴史はドラマである。現在第 2 幕が 終了して，次の幕が開かれようとしているといえよ うか。このような時期においては，とりわけ今まで 歩んできた歴史を振り返り，大局的な観点から核融 合エネルギーの将来を展望することが重要であろ う。

核融合のエネルギー利用としての研究は, 1950 年 代初頭に米英で開始された。その成果は 1958 年の国 連による「第 2 回原子力平和利用ジュネーブ会議」 において公開され，日本，ヨーロッパ諸国，ソ連を含 めて世界的に急速に核融合研究が拡大することにな
る。この初期の時代は楽観論が強く，英国のZETA ピンチで炉へのスケールアップが可能なプラズマ条 件が得られたと発表され，期待を集めるというよう なこともあった。ところがプラズマを安定に閉じ込 めることは，当初考えたほど容易なことではないこ とがわかってきた。そして, 1960 年代後半にかけて は暗闇の時代を迎えることになる。

昭和 $50(1975)$ 年の学術審議会の答申には, この困 難を克服していく過程が生き生きと述べられてい る。

「最近は長い暗中模索の苦闘の段階からようやく 脱却し，暗䦣の中に曙光がみえてきたということ ができる。それは 1969 年頃からり連のトカマク装 置の示した優秀な成果を基礎に解決の希望が見え てきたことによる。」そして，各国は競ってトカマ ク装置による研究プロジェクトに力を入れ始める ことになるが,「世界の核融合研究はいまやトカマ ク時代を迎えた観があるが，研究の現段階が依然 として探索的段階であるという特質を考え，各国 はトカマクに重点を置きつつも，他の方式への転 
換等も考慮して各種の方式について研究の努力を 続けている。」

とこの答申は分析している。

このような状況を受けて，原子力委員会は，昭和 50 年に我が国の「第二段階核融合研究開発基本計 画」を策定することになる。その基本的考え方とし て，「昭和 50 年代に臨界プラズマ条件達成を目的と する臨界プラズマ試験装置の開発を行うこととし， この成果を見て核融合動力実験炉,核融合動力炉の 開発を順次進めていくのが妥当である。としてい る。この臨界プラズマの条件は最近達成され，いよ いよ次の実験炉の段階へ進めるはずであったが，新 たな大きな壁に直面することになる。

今回の克服すべき最大の壁は，前回のものがプラ ズマを安定に閉じ込めることにあったのに対し，プ ラズマからのエネルギーの取出し方，すなわち熱と 中性子に関する問題にありそうである。このことは 核融合反応をエネルギー源として利用するためには 当然克服すべきこととして 10 年以上前から強く意 識され，体系的な開発計画の検討も行われてきた。 しかし，遠くから眺めていた壁に近づいて核融合燃 焼の段階に直面しょうとしている現在，この見上げ るばかりの高さの壁をどう越えていくかが，将来展 望の最大の課題となっている。

\section{2. 広い視野での将来展望の必要性}

本格的な核融合炉心の実験，あるいは実験炉に向 けた開発の進め方については,昭和 53 年頃から体系 的な検討が始められ，昭和 56 年には核融合会議にお いて，自己点火条件を目指した長期戦略がまとめら れている。特に広い視野から，炉工学等の専門家の 学際的協力を得て, 体系的に開発戦略の検討を行う べきとの観点から, システム解析の手法を用いた核 融合炉開発計画の評価も精力的に行われた。そこで は核融合エネルギーの利用の姿をとりあえず動力原 型炉として想定し，その目標に向けた開発のパスを どう描くか，その間にどのような炉心工学試験装置 や実験师を考えることが適当かが様々に議論され た。

このような検討は，当然のことながら炉心プラズ マの物理および炉工学技術の到達レベルに及び，開 発目標とする動力炉の概念設計研究のレベルに依存 する。しかし，いま振り返ってみると，抽象的では あるが現在直面している多くの課題はほほ 10 年前
に検討が行われていることに気付く。

例えば筆者も関係した核融合炉研究開発のシステ ム解析では，最も困難度の高い課題として，ダイバ 一タ等のプラズマ排気に伴う局所的高熱負荷への対 応と，DT 反応中性子による材料損傷の問題を挙げ ている。そしてそのリスク補償のため，前者に対し てはプラスマ排気の試験と電流維持定常化の試験を 行うため，水素プラズマでのロングパルスの炉心プ ラズマ試験装置を，後者については材料照射試験等 のための中性子源を提案している。

この 2 つの副次計画は，その開発計画全体の成功 確率やスケジュール・選択の柔軟性等への寄与が極 めて大きいとの評価結果を得ている(1)この 10 年間 の研究開発の進展には感銘深いものがあるが，基本 的な問題についてはあまり変わっていないことに改 めて問題解決の困難さというものを感じる。

我が国でのトカマク型実験炉や，いわゆる次期装 置の具体的な概念設計は原研を中心として精力的に 行われた。米国, ECでも炉心工学や炉工学への重点 の置き方の異なる様々な装置が提案された。また次 段階の装置の規模が大きく，一国単独での負担が容 易でないこと等から，国際協力によるINTOR 計画 も進められた。そして現在，各国が単独に独自に行 うのでなく日, 米, EC, ロシアが共同して，次段階の 自己点火トカマク実験炉の計画を進めることに合意 し,この ITER 計画に各国の核融合研究開発計画が 大きくシフトすることになった。

以上のような経過は何を物語っているのだろう か。個々の研究開発の成果や計画策定の経緯につい ては，よく議論され，評価もされているようである。 しかし全体として，核融合研究開発が現在どこまて 到達し，将来の魅力的なエネルギー源に向けてどの ように展望しうるものなのか。このような問いかけ に対し，多くの人は困惑を賞えるだろう。それは今 までの核融合の研究開発が，プラズマ閉じ込めが中 心課題であり，エネルギーシステムへ向けた展望に まで頭が回りにくかったことによるのかも知れな い。しかし，トカマク方式で第 2 段階の計画の目的 を達成したいま問われているのは，将来魅力的な工 ネルギー源となり得る可能性であり，またそのため 克服すべき課題と方策である。

このことは慣性閉じ込め方式についても同様にい える。またトカマク方式より優れた磁場閉じ込め方 式の探索についても,将来, より一層㰫力的なエネル 
ギー源となりうるための条件や，そのためのプラズ マ物理の研究が最重点課題となるはずである。核融 合研究開発が開始されて 40 年を経た現在,今までの 延長の発想でなく，大きな転換期にあるとの認識の もとに広い視野からの将来展望が必要となってい る。

「本特集」では，以上の観点から，開発段階や性格 の異なる方式や利用の仕方も含めて，核融合研究開 発全体を大局的に眺めるための将来展望を行う。そ のレビューに当っては, 将来のエネルギー源として の可能性をできるだけ具体的に，総合的に描けるよ う，各方式における実用炉の概念設計研究あるいは エネルギーシステムとしての可能性を重点的に紹介 する。そこては核融合炉の経済的可能性や安全性, 環
境保全性,プラント保守の容易さ等も含めて,できる だけ総合的にエネルギーシステムとしての可能性を 展望したい。もちろん現段階では，エネルギーシス テムとしての炉概念が充分詰められていない点も多 い。しかし細部の設計のフィージビリティでなく， むしろ問題は魅力的な核融合炉の概念がどのように 描けるか，またそれを現実に可能としていくために 何が課題であり，将来計画としていま何をすべきか にあり，この趣旨のもとに各方式についての将来展 望を行うこととしたい。

\section{一參考文献—}

(1) KohzaKI, Y., Kondo, S., SEKIGUCHI, T. : Systems analysis of a fusion R\&D program based on the GERT technique, J. Fusion Energy, 3, 473 (1983).

\section{II．トカマク型核融合炉}

日本原子力研究所 関

\section{1.はじめに}

核融合炉が将来のエネルギ一源となるには，環境 安全性,経済性および工学的実現性の面からみて,他 のエネルギー源と比べて遜色ない核融合動力炉の有 望な概念を示す必要がある。

魅力ある核融合炉概念を創出することを目標とし て, 原研において 20 年来トカマク型核融合炉の設計 研究を行なってきた。その結果を世界的な検討状況 とともに多少私見も交えて紹介する。

\section{2. 過去の( 1982 年)動力炉の検討}

1973 年 4 月に原研において核融合炉設計グルー プが組織され，まず核融合炉がいかにあるべきか」 を考えることから活動を開始した。当時は世界の各 研究所で核融合炉の概念検討 ${ }^{(1) \sim(4)}$ が開始されよう としていた時期であり，その時点で唯一の総合的な 設計は英国カラム研究所(5)でなされていた。この設 計は液体金属 $\mathrm{Li}$ を冷却材兼卜リチウム増殖材とし て使用し，Nbを構造材とするものであった。このよ うに扱い慣れない材料を使用しないと成立しないの では，核融合炉は当分ものにならないのではないか と考えられた。

そこで我々は，Heガス冷却でトリチウム増殖は $\mathrm{Li}_{2} \mathrm{O}$ セラミックスで行い, Incoloy-800を構造材と
するより現実的な概念を 1974 年に英国力ラム研究 所で開かれたIAEA「核融合炬に関する技術委員会 会合」に提案した(6)。第U-1図に示すブランケット 概念は当時としてはュニークなもので, 固体増殖ブ ランケットの先鞭をつけるものであった。しかし， 期せずしてほぼ同時に米国ブルックへプン国立研究 所でも同様な固体トリチウム増殖材のブランケット 概念が提案されていた ${ }^{(7)}$ 。

その時以来，原研で行われたトカマク型核融合炉 の検討経緯を第 II-1表に示す。この中で注目された のは，分解修理を容易ならしめるためにトカマク炉 を水のプール中に設置するスウィミングプール型ト カマク動力炉(SPTR-P)であった 械を水中に置くことに対する抵抗感等により，それ 以上の検討はなされなかった。

海外では, 1980 年に米国アルゴンヌ国立研究所て なされたトカマク型動力炉 STARFIRE ${ }^{(9)}$ が，かな り完全な形で核融合师プラント全体を検討したもの として参考にされていた。この検討では，高周波に よりプラズマ電流を駆動し運転を定常化したこと， 蓄積する He の灰をポンプリミタで排気するなど， トカマク炉のあるべき姿を提案したものとして評価 が高い。

1982 年の SPTR-P 以降は動力炉の総合的な検討

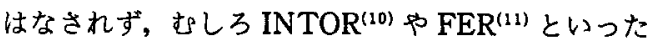
実験炉の概念設計が精力的に行われた。動力炉につ いては, その最重要な機器であるダイパータ, 第 1 壁やブランケットの実現性を高めるための設計検討 

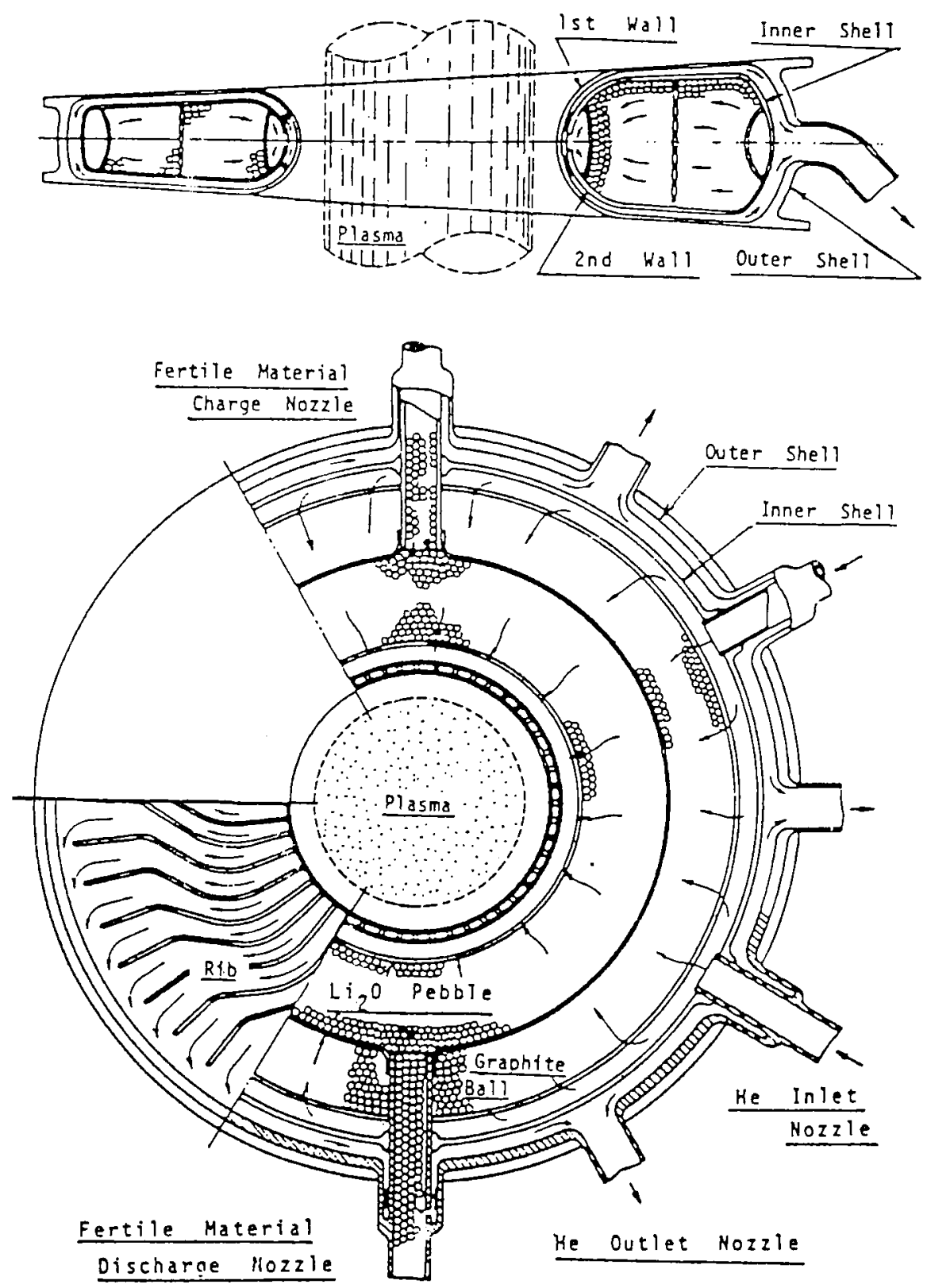

第 II- 1 図 インコネル 800 からなる $\mathrm{He}$ 冷却 $\mathrm{Li}_{2} \mathrm{O}$ プランケット

や小規模な実験的検討が進められた。

\section{3. 最近の (1988 年〜)核融合動力炉の検討}

1988 年になり，国際熱核融合実験炉(ITER)の概 念設計活動 ${ }^{(12)}$ が 3 年間にわたって EC, 日本, 米国
とソ連の協力により進められ，トカマク型核融合炉 の設計検討手法が飛躍的に進展した。また臨界プラ ズマ試験装置である日本の JT-60, EC の JET, 米国 のTFTRにおけるプラズマ物理実験から得られた 新しい知見を基に，新たに核曧合動力炉の検討が再 
第 II- 1 表 原研における核虽合炉設計の歴史

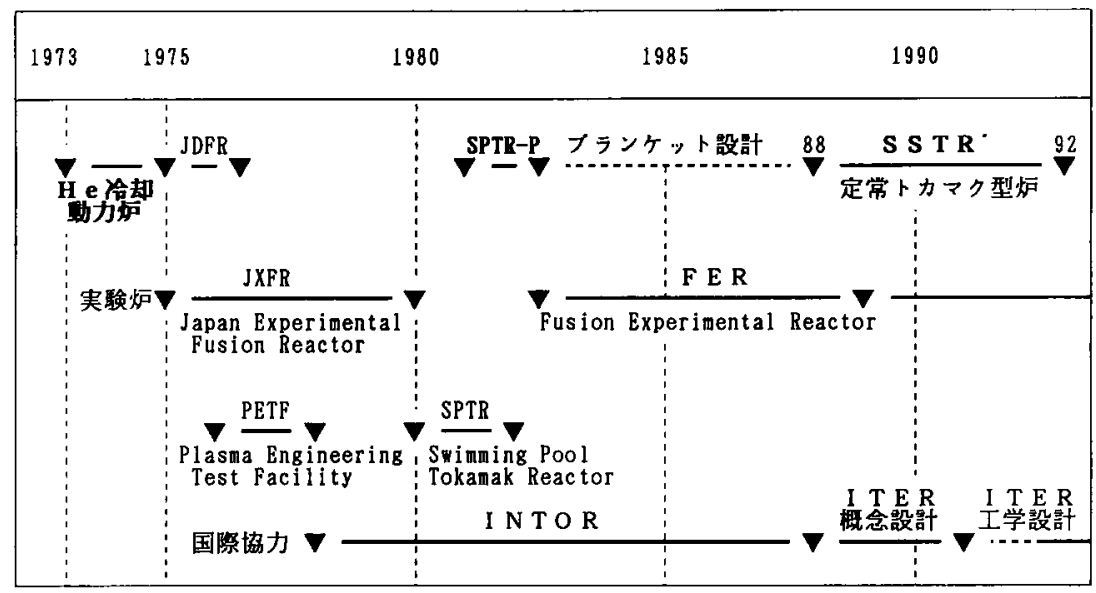

開された。

1982 年以来, 世界的にもト力マク型動力炉の検討 はなされていなかったが, 1988 年から米国において ARIES(Advanced Reactor Innovations Evaluation Studies) 計画(13) (15) が，そして我が国において 1990 年にSSTR(Steady State Tokamak Reactor) ${ }^{(16)}$ の検討が行われた。

\section{(1) ARIES 計画}

米国カリフォルニア大学ロスアンゼルス校 (UCLA)の Conn 教授をプロジェクトリーダーとし て ARIES 計画(1988〜92 年)では 4 種類のトカマク 型動力炉概念が提案された。

ARIES-I I(13) は 1990 年 6 月に検討を終了した炉 概念で,物理と工学に扔いてささやかな外挿 $(5 \sim 20$ 年間の技術的発展)を見込んだ概念であるとしてい る。ARIES-Iにおいては，高温の $\mathrm{He}$ 冷却との整合 性が良く，また放射化が少ない $\mathrm{SiC}$ 複合材料を主要 構造材として採用し，安全性を高めた設計となって いる。また最大磁場強度 $24 \mathrm{~T}$ の超電導マグネット を使用しているなど相当な技術的進歩を見込んてい る。

ARIES-III (14) は 1991 年に完成したD-3 $\mathrm{He}$ 燃料 サイクルを利用する炬概念である。これは NASA がアポロ計画で月面において発見した ${ }^{3} \mathrm{He}$ 資源を 利用することを提案したことにより前倒しで検討さ れたものである。 $\mathrm{D}^{-3} \mathrm{He}$ 然料サイクルは，中性子発 生が少なく，トリチウムを燃料として使わないなど 環境安全面の利点はあるものの, シンクロトロン放 射によるエネルギー損失を反射率の高い材料により
低滅させることなど，多くの克服すべき工学的な課 題が明らかにされた。

また, 理論的に予測されている $10 \%$ 以上の高い $\beta$ 值をもつプラズマが実現することなど, ARIES-I よ りさらに先進的な物理条件を取り入れた炉概念を ARIES-II と-IV ${ }^{(15)}$ として検討中であり，1992 年中 に終了する予定である。

\section{（2）定常トカマク核融合炉(SSTR)}

核融合の研究開発が第 3 段階に入るに際して, 将 来の核融合炉の姿をより明確にするために，原研で は最新の物理データベースと核融合炉工学の進展に 基づき，現存技術の僅かな外插により ITER の次に 建設できる核融合動力炉の検討を行なった。実現性 の高い核融合動力炉の基本概念として，定常卜カマ ク核融合炉(SSTR) ${ }^{(16)}$ の概念を提案した。ここで定 常という意味は, 通常のトカマク装置では変圧器の 原理を利用してプラズマ電流を流すためにパルス状 の運転となるが,ここ SSTR では, JT-60 実験で確 認されたプラズマ中に自発的に流れるブートストラ ップ電流を最大限に利用して, 外部から補助的に駆 動する電流と合わせて定常的な運転を行うトカマク 動力炉である。その概念図を第 基本諸元を第

第II-2 表に見られるように, SSTR ではプラズ マ半径 $a$ に比べてトーラス半径 $R$ が大きい高アス ペクト比 $(A=(R / a)=4)$ と強磁場 (16.5T) を選択 し，これによりプラズマ電流を，この規模の装置と しては低い12 MAに抑えることに成功した。その 結果, 比較的コンパクトな装置規模で, 出力 100 万 


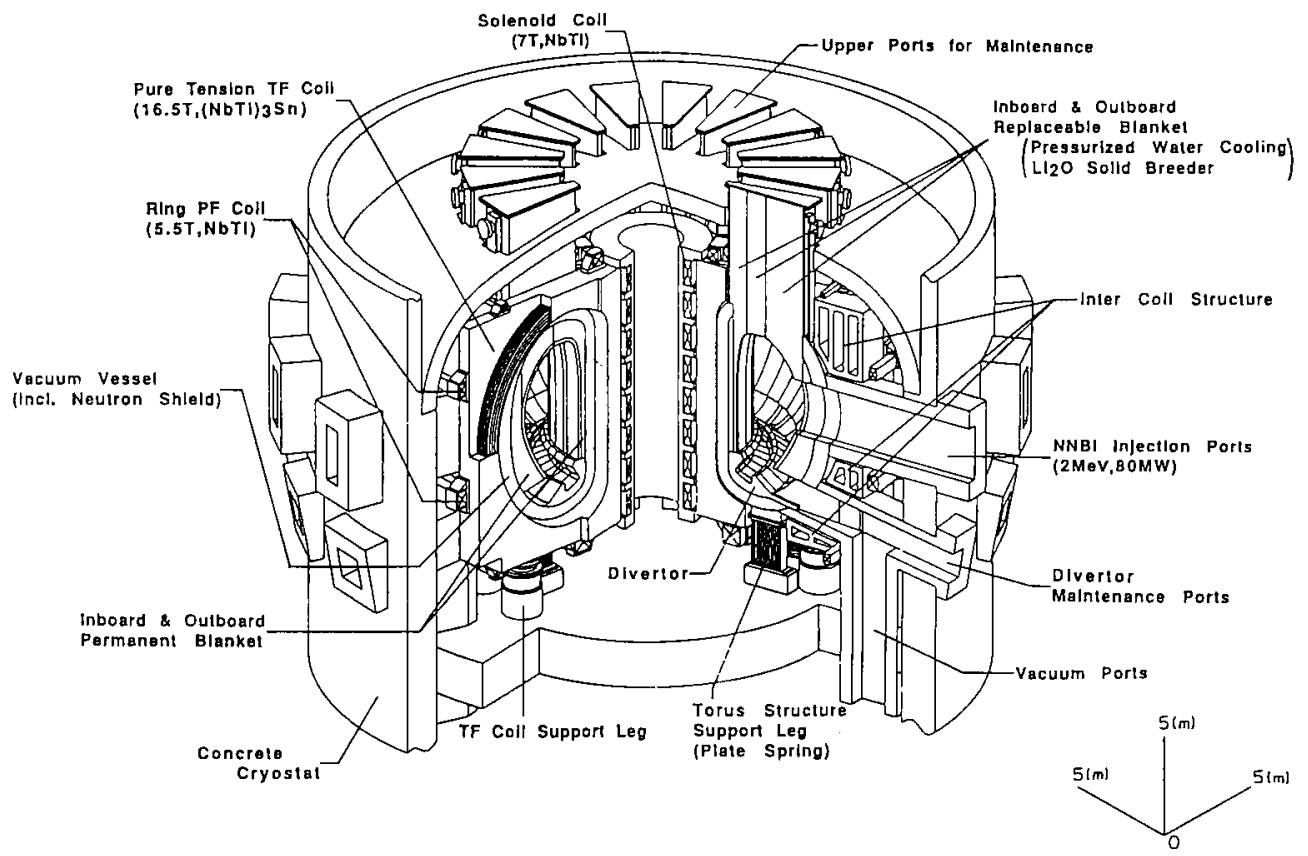

第II- 2 図 SSTR 核融合動力炉の鳥瞰図

第 Ш-2 表 SSTR の基本諸元

\begin{tabular}{lc}
\hline & 基本諸元 \\
\hline 主半径 & $7.0 \mathrm{~m}$ \\
小半径 & $1.75 \mathrm{~m}$ \\
アスペクト比 & 4 \\
プラスマ体積 & $800 \mathrm{~m}^{3}$ \\
プラズマ電流 & $12 \mathrm{MA}$ \\
ブートストラップ電流 & $8 \mathrm{MA}$ \\
最大トロイタル磁場 & $16.5 \mathrm{~T}$ \\
超電導線材 & $(\mathrm{NbTi})_{3} \mathrm{Sn}$ \\
トリチウム増殖比 & 1.0 以上 \\
冷却材出入ロ温度 & $285 / 325^{\circ} \mathrm{C}$ \\
核瀜合出力 & $3.000 \mathrm{MW}$ \\
正昧電気出カ & $1.000 \mathrm{MW}$ \\
入射加熱パワー & $80 \mathrm{MW}$ \\
入射加熱式 & 負イオン源中性粒子入射 \\
入射ビームエネルギー & $2.0 \mathrm{MeV}$ \\
運転モード & 定 常 \\
\hline
\end{tabular}

kWeの動力炬となっている。プラズマの加熱と外部 から供給する電流の駆動はともに，加速電圧 $2 \mathrm{MeV}$ の負イオン源中性粒子入射によって達成される。

SSTR の炉工学面での大きな特徴は, 中性子遮蔽 体と真空容器を一体化して，トロイダル方向には電
気抵抗がほほ一様な均一抵抗型真空容器の採用であ る。また，第 1 壁と一体化したブランケット前半部 だけを 2 年間に 1 回の割合で定期交換すること, 金 属とセラミックス絶縁材との傾斜機能材料の利用に より, 強度を維持しつつ渦電流を減らし電磁力を大 幅に低減したこと，低放射化フェライト鎆の採用に よる長寿命放射能の低減などの新しい考え方を採用 している。ただし，SSTRは，現存技術からの僅か な外挿で建設可能なことを目標とした動力炉概念て あるので, 1 次冷却材には軽水を 150 気圧, 入口/出 口温度 $285 / 325^{\circ} \mathrm{C}$ の加圧水炉条件で用いている。 SSTR の成立性に関わる最大のキーポイントは, 不純物注入等により，ダイバータの熱負荷が低隇で きるかである。また $70 \%$ \%上の稼動率を達成する上 でダイバータ,ブランケット等の寿命の確保とそれ らの交換に要する時間の短縮も重要である。工学面 での最も大きな開発課題は, $(\mathrm{NbTi})_{3} \mathrm{Sn}$ 超電手線材 を用いる最大磁場 $16.5 \mathrm{~T}$ のトロイダル磁場コイル および加速電圧 $2 \mathrm{MeV}$ の負イオン源中性粒子入射 装置てある。

\section{4. 核融合炉の評価}

未だ実験炉も出来ていない段階で，核融合炉の経 
済性を論ずることは時期尚早の感もあるが，核融合 炉の経済的成立性を調べるためあえて核融合炉の 発電コストを軽水炉のコストと比べてみる。

例えば，SSTR の正味電気出力当りの建設費は， 軽水师の約 2 倍程度と SSTR 設計チームによって 評価されている(16)。発電単価に占める資本費の割合 は $70 \%$ に達する。核融合炉のブランケットは定期的 に交換する必要がありこれを含んだ燃料コストは 無視できない值(発電コストの $10 \%$ 前後)となる。こ の燃料コストは許容される最大中性子フルエンスに よって左右される。耐用年数を 16 年, 稼動率を $70 \%$ とした場合の核融合動力炉の発電コストは軽水炉の 約 1.5 倍と見積られた ${ }^{(16)}$ (発電コストの見積りに際 しては多くの仮定がありこれらの仮定については， 今後の検証が必要である)。核融合動力炉に期待され る各種の技術的進歩を考えれば，将来さらに合理化 と技術革新により経済性が向上する可能性がある。

今後，全地球的な炭酸ガス排出量制限のために化 石燃料の多量消費はますます困難になると予想さ れ，化石燃料による発電を低減していく必要がある。

他方, 現在の技術の延長上では 100 万W クラス のトカマク型核融合炉の発電コストを軽水炉よりも 低くすることは，かなり困難である。核融合炉はス ケールメリットが顕著であり，また建設費の償却の 仕方と利子率により資本費は低下する可能性があ る。

また,核融合炉の重要な長所はその安全性である。 核融合炉は以下の固有な安全特性により，核分裂炉 よりも格段に環境・安全面で受容され易くなる可能 性がある。

（1）核融合炉には臨界事故がない。

(2) D-T 核融合反応の生成物は中性子と $\mathrm{He}$ 原子であるので，核融合炉では核分裂生成物 やアクチノイド核種は発生しない。
（3）崩壊熱密度は核分裂炉より低いので，その

除去は比較的容易である。

D-T 核融合炉の環境・安全面への懸念要因は，主 として燃料として使用されて核融合炉プラント内で 再生産されるトリチウム, D-T 核融合反応から生成 される $14 \mathrm{MeV}$ 中性子，およびこの中性子と炉の機 器の構成材料との相互作用によって生ずる放射化生 成物である。トリチウムのインベントリーは，トリ チウム再処理量を低減し得る進歩したプラズマの運 転方式，およびクライオポンプをトリチウムイン心゙ ントリーが低いターボ分子ポンプで置き換えること など, トリチウム燃料循環系等の機器の開発進歩に より滅少させることができる。

一般公衆と作業員の放射線被曝線量は適切な遮蔽 設計によって合理的に達成できる限り低減させる。 放射化生成物に関しては，量は多いがそのほとんど が金属中に永久に捕捉されており，その可動化は充 分に低減できよう。将来的には，低放射化材料の導 入により，放射化生成物を飛躍的に減らすことが期 待できる。

将来, 核融合炉が高い社会的受容性を獲得すれば， 核融合炉発電所の敷地確保が容易になり，さらに大 都市に近接して設置することにより送電コストの低 減が可能となる。結論として，核融合炉は今後の技 術開発に基づいて獲得される経済性の向上と, 本来 有する高い環境·安全性によって社会的受容性の高 い良質なエネルギー源となることが期待できる。

\section{5. 今後の課題}

核融合炉の将来の展望を第 と SSTR からの外挿によれば，今後機器, 材料等の 研究開発の進歩によって,トリチウムと放射化生成 物のインベントリーの低隇が期待される。核融合炉 の安全特性は, 軽水の代わりに He を冷却材として

第 I-3 表 ITER, SSTR および将来の核融合動力炉の環境・安全面のパラメータ比較

\begin{tabular}{|c|c|c|c|}
\hline 項 目 & ITER & SSTR & 将来の動力炉 \\
\hline 核融合出力（GWt） & 1 & 3 & 4.5 \\
\hline トリチウム装荷量（kg） & 6 & 5 & 3 \\
\hline 放射化生成物装荷量（Ci） & $\sim 10^{9}$ & $<10^{9}$ & $\ll 10^{9}$ \\
\hline /粪造材 & $/$ SUS-316 & ／低放射化フェライト鋼 & $/ \mathrm{TiAl}, \mathrm{SiC}$ \\
\hline 1 次冷却材 & 軽 水 & 軽 水 & $\mathrm{He}$ \\
\hline 冷却材入口/出口温度 $\left({ }^{\circ} \mathrm{C}\right)$ & $60 / 100$ & $285 / 325$ & $400 / 700$ \\
\hline 熱効率（\%) & - & $\sim 30$ & $\sim 40$ \\
\hline
\end{tabular}


使用することにより一層改善できる。さらに冷却材 の高温化による熱効率の大幅な向上を望むことも可 能である。

SSTR を基本概念として，さらに安全性と経済性 を向上させた改良定常トカマク核蜝合炉(SSTR$2)^{(17)}$ の概念の検討を進めている。SSTR-2におい ては高温ガス冷却ブランケットシステムを検討し た。出口ガス温度は $700^{\circ} \mathrm{C}$ に設定し, 高温ガス冷却炉 並みの総合熱効率 $40 \%$ 発電系を想定した。

最高 $900^{\circ} \mathrm{C}$ まで使える高温構造材として, 主とし て航空宇宙関係の機体構造材料やエンジン部品への
適用が期待されているチタンアルミ(TiAl) 金属間 化合物を採用した。またガス冷却の伝熱性能の低さ を補うため, $\mathrm{He}$ 中に炭化ケイ素 $(\mathrm{SiC})$ 微粒子を入れ た固気混相冷却のブランケットとダイバータの概念 検討を進め, $\mathrm{He}$ 圧力と体積流量の低減を達成した。 SSTR-2 He 冷却ブランケットの概念図を第 II - 3 図に示す。今後も，固気混相流冷却ブランケットと ダイバータの検討を墚めるとともに，経斉性向上に 大きく貢献する炉内機器交換法の検討を進める予定 である。

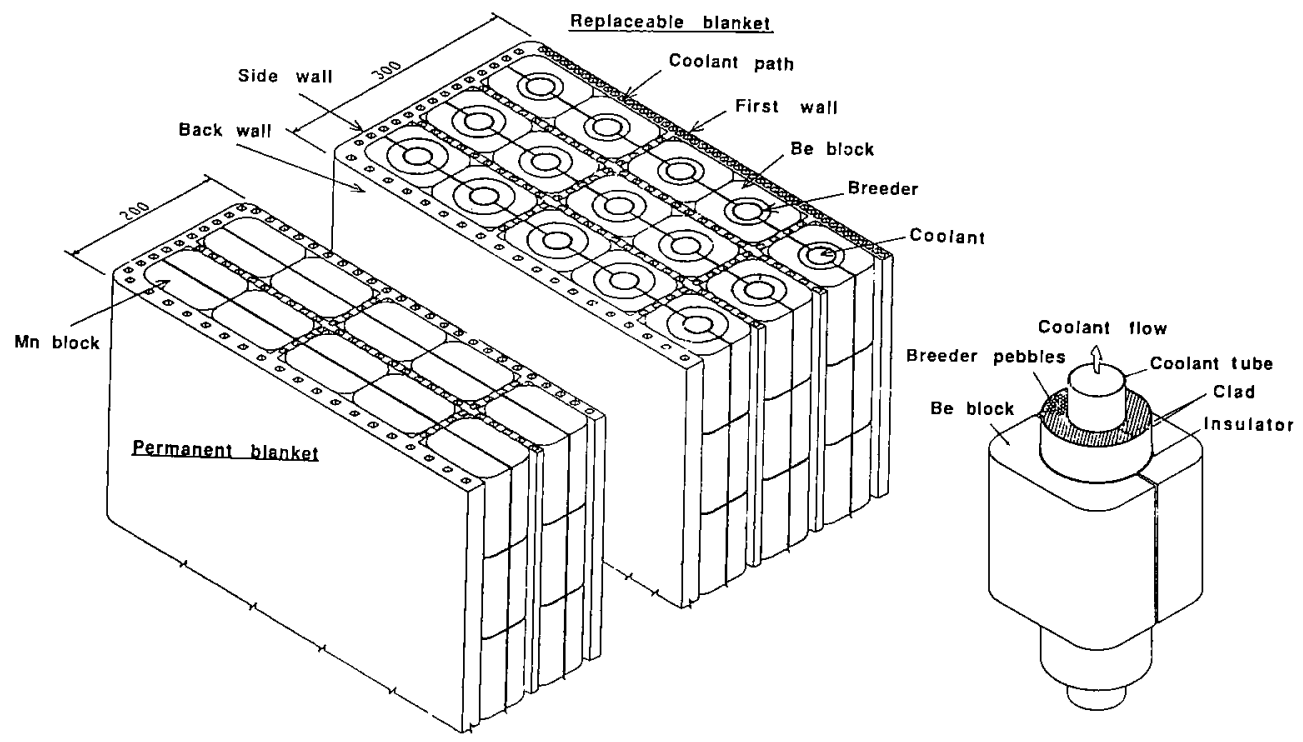

第 I- 3 図 SSTR-2 ブランケットの概略図

\section{一參考文献一}

(1) FRAAS, A. P.: ORNL-TM-3096, (1973).

(2) MiLLS, R. G., et al.: MATT-1050, (1974).

(3) Kulcinski, G. L., Conn, R. W.: Proc. Conf -740402 , Vol. 1, 38 (1974).

(4) BERTOLINI, E., et al.: ibid., 21.

(5) Hancox, R.: Proc. Int. Conf. on Nuclear Energy Solutions to World Energy Problems, ANS, (1972).

(6) SAKO, K., et al:: Nucl. Fusion Special Suppl., 1974, Proc. Symp. Fusion Reactor Design Problems, 27 (1974), IAEA.

(7) PoWelL, J. R., et al.: BNL-18326, (1973).

（8）東稔達三, 他：トカマク型動力怩システムの概念検討( ス ウィミングプール型)，JAERI-M 83-120, (1983)

(9) BAKER, C. C., et al.: $A N L / F P P-80-1$, (1980).
(10) INTOR, Int. Tokamak Reactor, Report for Zero Phase, Phase One, Phase Two A (Part I); Phase Two A (Part II); Phase Two A (Part III), (Published respectively in $1980,1982,1983,1986$ and 1988 by IAEA)

(11) 原研 FER 設計チーム：JAERI-M 88-090, (1988).

(12) TOMABECHI, K., et al.: ITER Documentation Ser. No.2 and 3, (1991), IAEA.

(13) CoNn, R. W., NaJMABADI, F.: $I A E A-C N-53 / H-I-4$ Nucl. Fusion Suppl., 659 (1991).

(14) NAJMABADI, F, et al:: Proc. 14th IEEE/NPSS Symp. Fusion Engineering, San Diego, (1991).

(15) NAJMABADI, F., CONN, R. W., ARIES Team : Fusion Technol., 21, 1721 (1992).

(16) Fusion Reactor System Lab.: JAERI-M 91-081, (1991).

(1) MORI, S., et al.: Fusion Technol., 21, 1744 (1992). 


\section{III. ヘリカル型核融合炉}

\section{核期合科学研究所 本 島 修}

現在，我が国においては文部省核融合科学研究所 を中心として, 環状磁場閉じ込め装置であるへリカ ル型装置の研究が鋭意推進されている。大半径 3.9 $\mathrm{m}$, プラズマ小半径 $0.65 \mathrm{~m}$, プラズマ体積 $30 \mathrm{~m}^{3}$, 磁 場強度 4 丁 の超伝導大型ヘリカル装置が建設中で あり(1)，臨界プラズマ条件の一步手前にターダット を定め, 無電流定常プラズマについて種々の物理実 験が計画されている。本計画は, 当然のところ, 定 常核融合炉の実現を目指したものであり，平成 9 年 度の実験開始以降得られるデータベースは，核融合 炉の開発研究の推進の上で大いに役立つものと期待 できる。したがって，炉設計を中心とする研究のア クティビティは, 過去の成果を踏まえるとともに LHD(Large Helical Device) 建設の進行に合わせ, LHD 以降を見通すための重要な研究として位置づ けられている(2)。

ヘリカル型装置における平衡と安定性は，プラズ マの外に置かれたへリカル・コイルに流れる電流に より達成される。本章で紹介するへリオトロン $\mathrm{H}$ 型 炉は, 中でも磁力線の回転変換角 $(\iota)$ とシアー $(\theta)$ の 大きいへリオトロン磁場を採用している。しの值は 半径の $1 / 2$ より外側では 1 より大きく, シアーの值 もプラズマの境界では 0.5 に達する。大きな回転変 換角とシアーの存在はプラズマの安定化に有効であ $\eta$, 限界 $\beta$ 值(プラズマ圧力/磁場の圧力)を高く取 れることが期待され，炉の経済性を高めることがで きると考えられている。プラズマの拡散についても， より低いレベルに抑えることが期待できる。

第血- 1 図にへリカル型装置の原理図を示す。プラ ズマの外に置いたコイルで, プラズマの平衡と安定 性を得るへリカル型装置の基本原理は, プラズマ中 に電流(ジュール電流と呼ばれる)を必要としないこ とを意味しており，定常的な運転が可能となる。こ のへリカル型炬の基本的な性質は，定常化のために は高効率の電流駆動が必要とされるトカマク型炉と は対照的なものである。これにより繰り返し熱応力 から解放されるとともに，電流を流して制御する唇 大な丽流とコイル・システムが不要となり,全体をシ ンプルな構造にまとめることができる。また，電流

がなければ電流の激しい切断(ディスラプション)現 象からも解放されるわけで, 設計の安全率を高める ことにも役立つ。

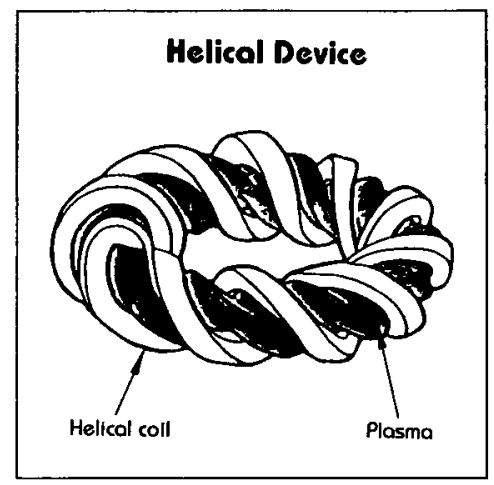

第M-1図 ヘリカル型装置の原理図

核融合炉の場合，プラズマと壁との相互作用の問 題, 特に第 1 壁への熱負荷.と冷却，および材料の選 択が重要な問題になる。へリカル型炉の場合は，プ ラズマの境界がへリカル磁場の最外殸磁気面で決定 されるため(磁気りミ夕配位)，この相互作用を積極 的に制御することが可能である。つまりプラズマと 壁との距離を有限に取ることができるため，その值 をプラズマのパラメータによらず一定に保つことが できる。電流の変化や何らかの不安定(MHD的)に 伴ってプラズマの境界が変化することがないわけて ある。プラズマの境界のすぐ外側の磁力線を使えば ダイバータの設計も可能でありこのつくりつけの ダイバータは D-T反応で生じる灰の排出や不純物 の排出に重要な機能を発揮することとなる。

以上がヘリカル型炬を設計する場合の基本的な物 理概念である。

第吕- 1 表にヘリカル型動力炉 (ヘリオトロン $\mathrm{H}$ )

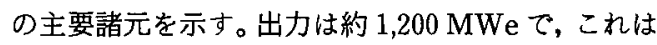

第III-1 表 ヘリオトロン $\mathrm{H}$ 炉の仕様

Major radius

Minor radius of helical coil

Magnetic field

Neutron current

Thermal power

Net electrical power

System power density

Thermal conversion efficiency
$21.0 \mathrm{~m}$

$3.2 \mathrm{~m}$

$4.0 \mathrm{~T}$

$1.3 \mathrm{MW} / \mathrm{m}^{2}$

$3,400 \mathrm{MW}$

$1,190 \mathrm{MW}$

$0.41 \mathrm{MW} / \mathrm{m}^{3}$

0.35 
現在の発電プラントの標準的な出カレベルである。 装置のアスペクト比が大きいため出力レペルを下げ ることが課題になるが，最終的な商用炉として 100 万 $\mathrm{kWe}$ 級の炉が設計可能であることは，炉の第 1 条件を満たしていることを意味する。アスペクト比 が大きいことは装置へのアクセスが良いことを示し て抢り,サポート構造物や加熱装置, 真空排気装置と いった附属機器の取付けに有利な条件となる。

プラズマの限界 $\beta$ 值を平均で $6 \%$ に見込んでい
るため磁場の強さを $4 \mathrm{~T} に$ 設定している。コイル表 面での最大磁場は軸上での值の 2 倍程度になり，8 T強の值になるが，この值なら超電導材として NbTi を使用することができる。トロイダル・コイル に比べ形状が複雑なへリカル・コイルの場合,より製 作に適した NbTi の使用は, 設計上の重要なポイン トとなる。炉のポロイダル断面図, 平面図, 全体図を 第III- 2 図(a)〜(c)k示す。

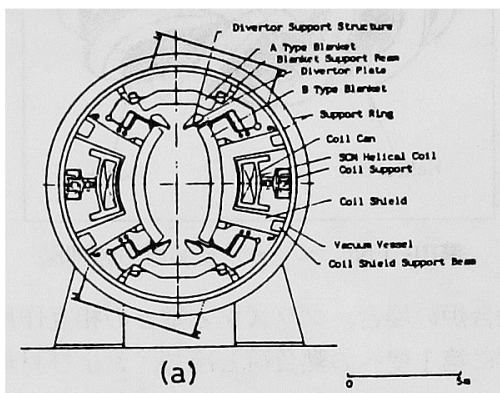

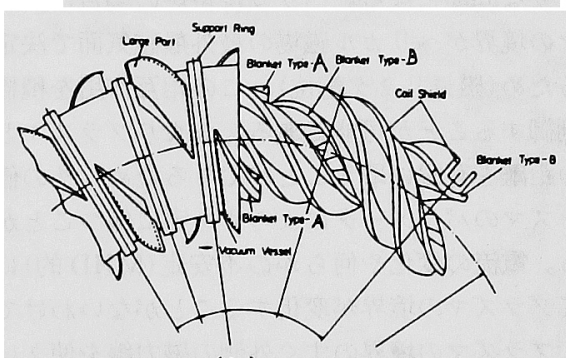

(b)

ヘリカル型炬の開発研究には，卜カマクに代わり 得る優れた性能に対する具体的かつ斬新なアイデア がその研究の出発点として必要であり，これが強く 求められてきた。逆にいえば, 最終目標である動力 炉の実現に関し，炉のあるべき姿を炉設計研究の手 法で予測することは, 現在の研究レベルの自己評価 にもつながり，より優れた研究路線の構築へと発展 させることに役立つのである。例を挙げれば，沶心 を占う閉じ込めのスケーリング則は, 現時点の実験 データに基づくわけであり,電力の単価を決める主 たる要因となる。逆に炉設計で前提とすべき物理扔 よび工学的な設計条件の大部分は, 現時点での研究 の主要テーマとなると思われる。これも例えていえ ば，大型へリカル装置におけるダイバータによる閉 じ込めの改善を目指す研究が良い例である。ここで 強調したいことは，それぞれの方式について，現在

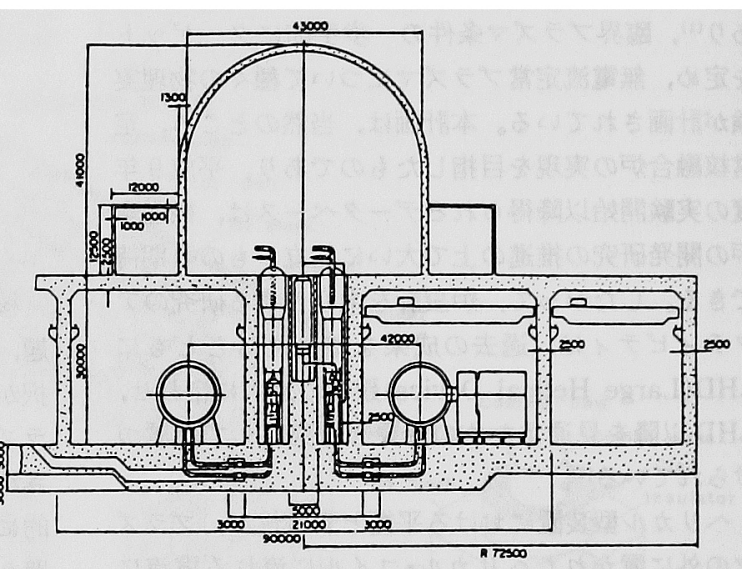

(c)

（a）ポロイダル断面図，(b) 平面図，(c) 全体図 第孟- 2 図 ヘリオトロン $\mathrm{H}$ 炉

の実験のシナリオと炉設計がコンシステントになっ ていることの必要性であり，どちらかでそれが破れ れば，その研究路線は放棄せざるを得なくなること である。今後は，炉設計に必要な炉心プラズマ物理 と炉工学を融合させた研究体制の整備と構築，およ び具体的成果の提示がより強く求められて行くこと になろう。

ここで別の観点でもう一つ意見をつけ加えておき たいと思う。それは，炉設計研究においては大胆な 仮定を置き，研究課題としてとらえる方法論の必要 なことである。これは新しいブレークスルーを見出 军効果的な近道でもあり，現有の装置の実験計画に 具体的な課題を与え，方向付けをすることにつなが ることである。

炉設計研究は，核融合炉工学のすべてを結集して 初めて結果を引き出し得るスケールの大きな仕事て 
ある。炉工学という言葉にあいまいなイメージがあ ると，各分野の研究者間の誤解のもととなり，全体 としてのコンシステンシーを欠くことともなるう。 よく知られている通り, 昵工学には大きく分類して (1)超伝導, (2)プラズマ対向材料, (3)中性子工学, (4)構 造材料, (5)機械工学, (6)卜リチウムハンドリング,(7) 熱工学, (8)加熱装置, (9)すべてを包含する形ての炉設 計,等の広い分野にまたがる。これらの分野ではそれ ぞれ独自の研究テーマを有し, かつ独自の研究のモ ティベーションに基づき発展した経緯を有してい る。例光ば，低放射化材料，高耐熱負荷第 1 壁材料， 高磁場, 高電流超伝導導体等の開発など,多くの独立 かつ重要なテーマを包含しているわけである。

核融合炉の基礎的な開発研究のためには，へりカ ル型装置に限らず，大学を中心として多方面の分野 の研究者の有機的なネットワーク作りが必要である
が,これは容易なことではなく、核となる組織(また はグループ)の必要性が過去より炉工学関係者によ り強く指摘されてきたところである。研究者の層を 厚くすること等を含めて多くの努力が続けられてい るが, 各主要大学に設置されている原子力教室への 期待には大きいものがあることを申し述へてておきた い。核融合科学研究所に扔いても得意な分野として, 超伝薄, 第 1 壁, 加熱技術を中心とする炉工学分野の 研究はすでに開始されており, 前述の認識の下に, 国内の共同研究を活用しての本格的な炉設計計画が 開始されようとしている。次の機会にさらに進んだ 研究の成果を紹介したい。

\section{一参考文献—}

(1) Motojima, O., et al. : Plasma Physics and Controlled Nuclear Fusion Research, 3, 513 (1990).

(2) Motolima, O., Iryoshi, A., Uo, K.: ibid., 3, 209 (1983).

\section{D- ${ }^{3} \mathrm{He}$ FRC 核融合炉}

核融合科学研究所 百田 弘

\section{1. $D^{3}-\mathrm{He}$ 核融合の必要性}

制御核融合は質量数 10 程度以下の比較的軽い原 子核同士の反応を利用して, 21 世紀以降の社会に主 要エネルギーを提供しようとするものである。日本・ 米国・欧州連合・旧ソ連等を中心としたこの研究開発 はトカマク型プラズマの開発とともに着実に進展 し，現状で核燃焼プラズマの実現を見込むに至った。

これまで核融合開発は，核燃焼実現が最も容易な 核反応： $\mathrm{T}(d, n)^{4} \mathrm{He}+17.6 \mathrm{MeV}$ を利用した DT 核 融合を想定してきた。しかし，このDT燃料による 核融合炉では, 発生するエネルギーの $80 \%$ を占める $14 \mathrm{MeV}$ 中性子が，プラズマ容器や核融合炉の構造 材料に核変換や原子の吒き出し等の損傷をもたらす ので，材料の物性的性質の短期間での劣化が問題に なる。実際, 100 万 $\mathrm{kWe} の \mathrm{DT}$ 核融合炉て廃棄され る放射性物質は年間 $500 \mathrm{t}$ 以上と計算されており， この炬材料の損傷とその廃棄の問題は炉の経済性の みならず, 環境保全の観点からも，DT 核融合の実用 化にあたって解決すべき重要かつ困難な課題であ る。

D-3 $\mathrm{He}$ 核融合は $14 \mathrm{MeV}$ 中性子に由来する課題 を报本的に回避すべく，核反応： ${ }^{3} \mathrm{He}(d, p){ }^{4} \mathrm{He}+$
$18.3 \mathrm{MeV}$ を利用する。この反応自身は中性子を発 生しないが，これに付随するDDトリチウムの漏洩 過程での重水素との反応で DT 中性子を発生させ る。しかし，全体としては核融合エネルギーの 50 80\%程度が荷電粒子の運動エネルギーとして 放出され，中性子の割合を核融合出力の $1 \%$ 以下に 減少させることも可能で，DT核融合に見られた 14 $\mathrm{MeV}$ 中性子に由来する工学的課題は劇的に軽減す る。さらに,この核融合では，発生エネルギーの大部 分を受け持つ荷電粒子を高効率の直接エネルギー変 換器に導くことで, 非常に高効率の電カプラントの 構築が可能となる。

地球上での ${ }^{3} \mathrm{He}$ の供給量は年間 $50 \mathrm{~kg}$ 程度以下 で, 100 万 $\mathrm{kWe} の$ 実用核融合炉 1 基に燃料を供給し うる程度である。ただし，地球外では状況が全く異 なる。米国のアポロやソ連のルナが持ち帰った月表 面の泥サンプルの分析は, 深さ $2 \mathrm{~m}$ までの月表面で 100 万 $\mathrm{t}$ 程度の経済的に採鉣しうる ${ }^{3} \mathrm{He}$ の存在を明 らかにした。さらに遠将来的には，事実上無限量の 存在が推論される火星や木星の ${ }^{3} \mathrm{He} の$ 利用が考え られる。

\section{2. $\mathrm{D}^{-3} \mathrm{He}$ 核融合と FRC}

D- ${ }^{3} \mathrm{He}$ 燃料の燃焼温度は 40〜80 keV という高い 值なので，シンクロトロン輻射によるエネルギー損 失を軽減すべく非常に高いプラズマ $\beta$ 值と閉じ込 
めパラメータ: $n_{e} \tau_{E} \sim 2 \times 10^{21} \mathrm{~s} / \mathrm{m}^{3}$ が要請される。 また高効率の $\mathrm{D}^{-3} \mathrm{He}$ 電力プラントを構築すべく大 量の荷電粒子を処理して直接に電気エネルギーを発 生させる高効率・大電力の直接エネルギー変換器の 設置が要請される。

磁場反転配位 (Field-Reversed Configuration : FRC) は D-3 $\mathrm{He}$ 核融合によってその重要性が再認 識された。第IV-1図に示すように，燃料プラズマは トカマクと同樣にトロイダルプラズマ電流で磁気的 に閉じ込められる。ただ，トカマクがトロイダル磁 場によってプラズマがねじれようとする不安定性 (キンクモード)を安定化するのに対して, FRC はべ ータトロン加速器と同様に荷電粒子の慣性力でプラ ズマの傾斜モードを安定化させる。トロイダル磁場 がないので, プラズマの $\beta$ 值は 50〜 $100 \%$ という極 端に高い值になる。FRCの閉じ込め特性は非常に優 れたもので，そのエネルギー閉じ込め時間 $\tau_{E}(\mathrm{~s})$ は 経験式:

$$
\tau_{E} \sim 3.0 \times 10^{-5}\left(r_{s} \sqrt{\rho_{i 0}}\right)^{2.7} T_{i}
$$

で与えられる。ここに， $r_{s}$ はプラズマ半径 $(\mathrm{m}), \rho_{i 0}$ は外部磁場で定義したイオン旋回半径 $(\mathrm{m}), T_{i}$ は平

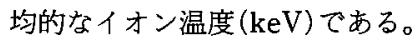

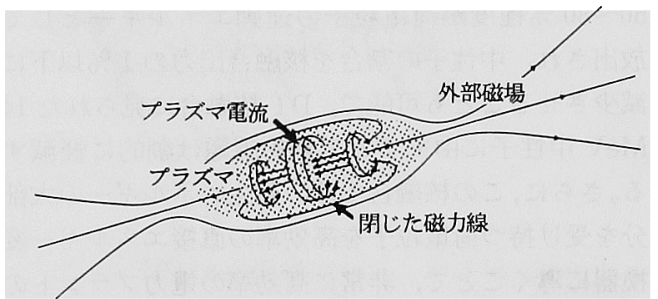

第IV-1图 プラズマ閉じ込め方式：FRCの概念

この高 $\beta$ FRC は実験室で再現性よく生成されて おりこれまでに非常に小型の装置で最大 $3 \mathrm{keV} の$ イオン温度と $0.5 \mathrm{~ms}$ のエネギー閉じ込めを達成 している。プラズマの外側は開放端型磁場で，この 磁力線に沿って荷電粒子を大電力の直接エネルギー 変換器に導入することが可能である。かくして FRC
は $\mathrm{D}^{-}{ }^{3} \mathrm{He}$ 核融合の要請条件に完壁に応えるもので, 実用核融合炉の有力候補たりうるものである。

イオンの慣性力が有効に機能してプラズマを安定 化するのは, プラスマ半径 $r_{s}$ と平均イオン旋回半径 $\rho_{i}$ との比で定義される $s$ 值が 4 程度以下の場合で, それ以上の $s$ 值では，例えば高エネルギー荷電粒子 ビームによる安定化等が必要である。D- ${ }^{3} \mathrm{He}$ FRC 核融合炉では，必要な閉じ込め性能を確保すべく $r_{s}$ $\sim 1.4 \mathrm{~m}$ が要請され，結果的に $s$ 値は 10 程度にもな る。幸いなことに, D- ${ }^{3} \mathrm{He}$ 燃料による FRC 核融合炉 では，核融合生成陽子の選択的捕捉によって安定な 高エネルギー荷電粒子ビームが自動的に形成され, これが配位を安定化すると同時に，配位の定常的維 持に必要な電流駆動にも大きく寄与する。かくして FRC 核融合炉は $\mathrm{D}^{-}{ }^{3} \mathrm{He}$ 燃料を導入することで自動 的にプラズマが安定化され，しかも定常運転が可能 になるなど，核融合炉として理想的な特性が得られ る。

\section{D-³ He FRC 核融合炉一アルテミス}

$\mathrm{D}^{-3} \mathrm{He}$ 燃料による FRC 核融合炉の魅力と開発課 題を具体的・定量的に明らかにする目的で，100万 $\mathrm{kWe}$ の核融合炉-アルテミスの概念設計が遂行され た。第IV-2 図に示すように，炉本体は生成部, 燃焼 部, 直接エネルギー変換部等で構築されている。

FRC は生成部で逆バイアス磁場テータピンチ法 によって生成される。ここで作られた FRCプラス マは直ちに燃焼部に移送された後, $1 \mathrm{MeV}$ 中性粒子 入射・D-3 $\mathrm{He}$ 燃料ペレットの注入・磁気的压縮等で 電流駆動とプラズマ加熱が行われ，同時に粒子密度・ 配位形状等が制御されて核燃焼状態に進化する。中

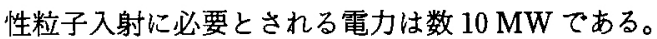
FRC核融合炉への燃料供給は「パックーマン法」て D-3 He燃料ペレットをプラズマの中心部に到達さ せることで可能になる。 $\mathrm{D}^{-3} \mathrm{He}$ 核燃焼はこの燃料注 入と核融合生成高エネルギー陽子ピーム電流を補助

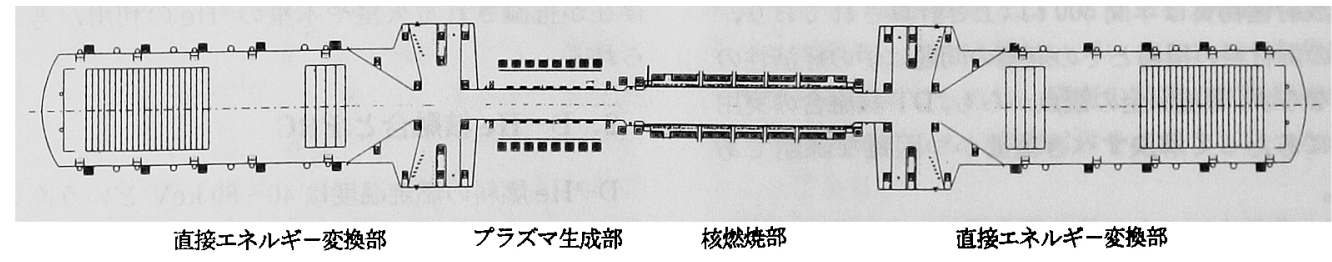

第IV- 2 図 D-3 He FRC 核融合炉アルテミスの全体図 
する数 $\mathrm{MW} / 100 \mathrm{MeV}$ 中性粒子入射によって定常的 に維持される。アルテミスの定常燃焼時の怩心パラ メー夕等が第IV-1 表に示されている。FRCの優れ た特性を反映して炉心は非常に小型である。

第IV-1 表 アルテミスの炉心パラメータ

\begin{tabular}{|c|c|c|}
\hline & 低中性子型 & 高効率型 \\
\hline 電子密度 $\left(\mathrm{m}^{3}\right)$ & $5.1 \times 10^{20}$ & $6.8 \times 10^{20}$ \\
\hline${ }^{3} \mathrm{He}$ と D との燃料比 & 1.35 & 0.5 \\
\hline プラズマ温度 (keV) & 83.5 & 85 \\
\hline プラズマ半径 $\times$ 長さ $(\mathrm{m} \times \mathrm{m})$ & $1.7 \times 22.2$ & $1.14 \times 17.4$ \\
\hline プラズマ電流 (MA) & 189 & 168 \\
\hline 外部磁場 (T) & 5.73 & 6.44 \\
\hline エネルギー閉じ込め（s） & 6.9 & 2.8 \\
\hline
\end{tabular}

この定常 $\mathrm{D}-{ }^{-3} \mathrm{He}$ 核燃焼状態では, 燃焼部で発生す るエネルギーの $50 \sim 80 \%$ が荷電粒子によって, 磁力 線に沿って直接エネルギー変換部に運ばれる。その イオン成分は漏洋燃料プラズマ粒子等と核融合生成 陽子である。電子はイオンより速く逃げ出して直接 エネルギー変換器のカスプ型電子収集器に到達する 結果, プラズマ電位は正となる。イオンはこの正電 場で加速され，その運動エネルギーをカスプ型イオ ン収集器で静電エネルギーに転化させる。 $\mathrm{D}-{ }^{3} \mathrm{He}$ 核 融合で生成される $15 \mathrm{MeV}$ の陽子は，イオン収集器 を通過して進行波型直接エネルギー変換器に導入さ れ，そのエネルギーを高周波の電気エネルギーに転 化させる。アルテミスでは, 漏洩プラズマ粒子のた めのカスプ型直接エネルギー変換器と, 核融合生成 陽子のための進行波型直接エネルギー変換器の効率 は，それぞれ $64 \%$ \%うび76\%と見積られる。

D- ${ }^{3} \mathrm{He}$ FRC 核融合炉アルテミスの主要諸元を第 IV-2 表に揭げる。炉は非常に小型で, 総合プラント 効率は非常に高く，また $14 \mathrm{MeV}$ 中性子の壁負荷は
第IV-2 表 D- ${ }^{3} \mathrm{He}$ FRC 核融合炉アルテミスの主要諸元

\begin{tabular}{lcc}
\hline & 低中性子型 & 高 効率 型 \\
\hline 核融合出力 $(\mathrm{MWt})$ & 1,800 & 1,650 \\
中性子出力 $(\mathrm{MWt})$ & 33 & 76 \\
放射出力 $(\mathrm{MWt})$ & 480 & 590 \\
第 1 壁熱負荷 $\left(\mathrm{MW} / \mathrm{m}^{2}\right)$ & 2.0 & 2.0 \\
第 1 壁中性子負荷 $\left(\mathrm{MW} / \mathrm{m}^{2}\right)$ & 0.104 & 0.423 \\
$\mathrm{DEC}$ 容量 $(\mathrm{MW})$ & 1,122 & 1,217 \\
綕合プラント効率 $(\%)$ & 55.6 & 60.2 \\
\hline
\end{tabular}

$0.05 \sim 0.26 \mathrm{MW} / \mathrm{m}^{2}$ にまで軽減されている。

\section{4. 結論と今後の課題}

概念設計アルテミスにみられた $\mathrm{D}^{-3} \mathrm{He}$ FRC 核 融合炉のための技術は, 最新の超伝導マグネット技 術や材料技術等を基礎に十分開発可能なものであ る。中性子照射に対する炬構造材料の寿命も $40 \sim 100$ 年以上である。 $\mathrm{D}^{-3} \mathrm{He}$ 核融合本来の特長で ある優れた安全性·環境保全性に加えて, 高 $\beta \mathrm{FRC}$ を採用したアルテミスは非常に小型で経済性に富む ものである。

これを実用化するに当たっての必要な開発研究 は, FRCプラズマ, とりわけ電子の異常輸送現象の 解明とその対策の確立扔よびそれに続くこの核融合 の原理実証実験である。また高エネルギー中性粒子 ビーム源と直接エネルギー変換器等の工学的研究が 必要である。工学プラズマの研究と並行に開発が可 能であり,このため例えば, 30 年以内での $\mathrm{D}^{-3} \mathrm{He}$ FRC 核融合の実用化も可能と考えられる。ただし， 月面等での年間 $1,600 \mathrm{t}$ 級 ${ }^{3} \mathrm{He}$ の採鉱プラントと地 球への運送が不可欠で,そのための月・惑星開発が急 務である。 


\section{V. 慣性核融合炉}

$$
\text { 大阪大学レーザー核虽合 三間 图興, }
$$$$
\text { 北川米喜, 中井 貞雄 }
$$

\section{1. 序 論}

慣性核融合炉は大出力のレーザー装置や重イオン 加速器 (エネルギードライバーと呼ばれる)からのビ ームパルスを重水素，三重水素の燃料ペレットに集 束・照射して高温高密度のプラズマを発生すること により，小型核融合爆発をチャンバ内で誘起してそ のエネルギーから電力を取り出すものである。その 構成は，(1)炉心プラズマ, (2)核融合炉チャンバ, (3)工 ネルギードライバー, (4)燃料システム, (5)冷却・発電 システム, (6)建屋からなっている。

炉心プラズマに関する研究は 1970 年代に開始さ れ，80 年代後半から急速の進歩を遂げている。その 結果, 炉心プラズマ実現へ向けてのシナリオが明確 になってきている。特に，1988～89年には高密度圧 縮が実証され(1)，炉心プラズマ発生に必要とされる 炬用レーザーの出力エネルギーが4 MJ程度に扔さ まることが明らかになった(第 V-1 図)。これと並行 して，米国ローレンスリヴァモア研究所のNOVA レーザーシステム(2)や, ロチェスター大学の OMEGAレーザーシステム泉によっても高密度圧 縮が実現された。これらの成果に基づき，米国では NOVA の高精度化と OMEGA の高出力化につき予 算措置がとられ，次期装置の建設が進行中であり， 米国エネルギー省 (DOE)の核融合諮問委員会 (Fusion Policy Advisary Committee) 慣性核融

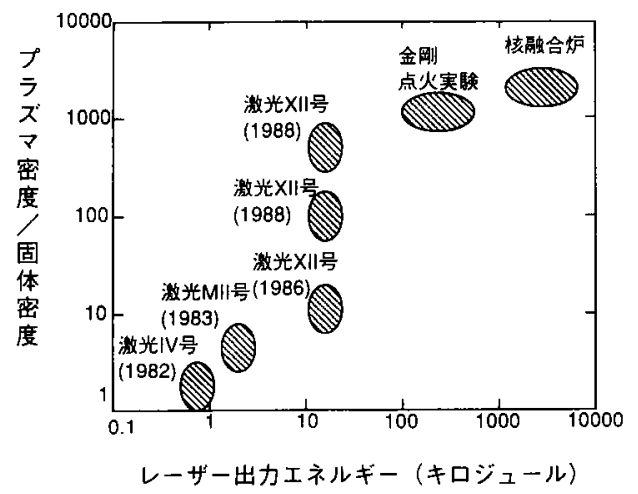

第V-1図 圧縮然料密度のレーザーエネルギー依存性
合と磁場閉じ込め核融合を同等に扱う必要があると の答申を出している。この答申に基づき, 点火・ブレ ークイーブンおよび核融合炉開発を目標に据えた研 究計画が推進されている。

上記の研究開発の進展に基づき, 精度のより高い 炉心プラズマ設計やドライバーの設計が行われてお り，末来の慣性核融合発電所への見通しがよくなっ てきている。レーザー核融合では，レーザー核融合 自己点火・ブレークイーブンを達成した後, MJ 級の レーザーを用いて高エネルギー利得の炉心プラズマ を実現する工学実験炉の開発が進められる(第 V-2 図)。

工学実験炉はそれに続く炉工学試験装置, 原型炉 を経て，核融合炉の実現化への展望を開くマイルス トンとなる。この工学実験と並行して, 炉用ドライ パーとなる $\mathrm{MW}$ 級の高繰り返しレーザーの開発が 進められる。高繰り返しレーザーおよびペレット製 作装置の開発の後には, 炉工学試験装置, 原型炉を経 て,遅くとも 2030 年までにはレーザー核融合発電所 を実現させる計画が考えられている。

\section{2. 炉心プラズマ}

核融合発電システムでエネルギーの流れの収支を 考えると, 核融合反応のエネルギー利得 $Q$ に対し, 発電効率 $\eta_{\text {conv }}$, 循環エネルギー率 $\eta_{\mathrm{rec}}$, ドライバー 効率 $\eta_{\mathrm{D}}$ を乗じたものが 1 になる。すなわち，

$Q \eta_{\text {conv }} \eta_{\text {rec }} \eta_{\mathrm{D}}=1$

となり，第 $\mathbf{V}-3$ 図のようなエネルギーの流れとな る。 $\eta_{\text {conv } は}$ は $40 \%$ 程度であり， $\eta_{\text {rec }}$ は 1/4 以下にす ることを要請し，レーザー効率 $\eta_{\mathrm{D}}$ を $10 \%$ にする と，エネルギー収支は $Q>100$ を要求することにな る。

大阪大学レーザー研において爆縮解析に用いられ ているILESTA コードによる設計では，第V-4 図 のような形状の固体 DT 然料層の上に $\mathrm{CH}$ のアフ

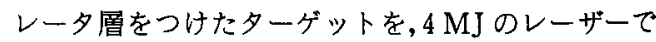
照射することにより，利得 150 以上を得ている。

爆縮の安定性の解析によると,上記の爆縮の場合, レーリーーテイラー不穴定性による非対称性の増幅 が 300 倍になる。したがって，球対称性を保持する ためには，初期のゆらぎが $0.3 \%$ 以下であることが 要求される。そのために, 32 ビーム以上のレーザー ビームを対称照射することが必要となる。 


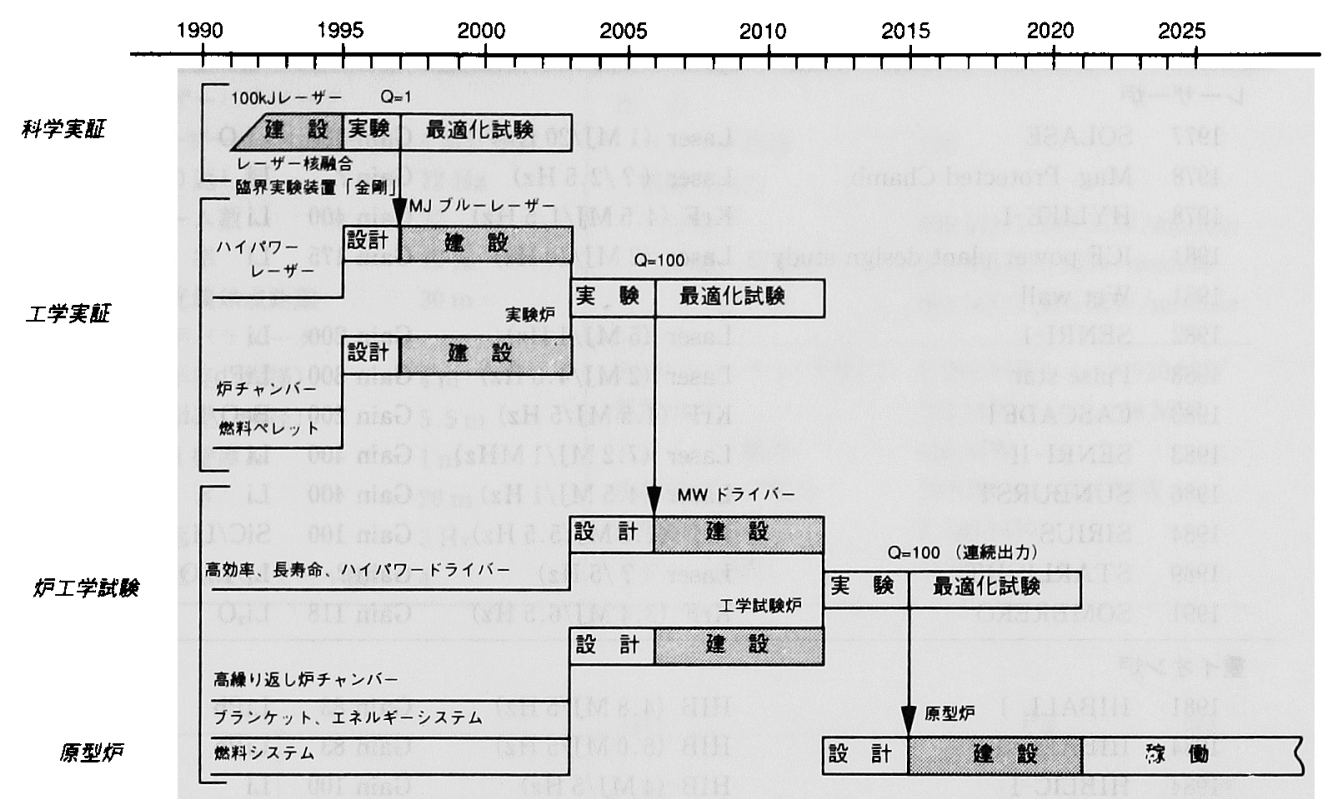

第 V-2 図 我が国の研究開発計画

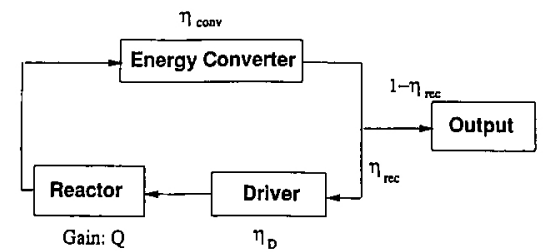

第V-3图レーザー核融合発電システム のエネルギー流れ図

\section{3. 慣性核融合炉の研究の現状}

毎秒数回のエネルギードライバーのショットによ り, 出力 $1 \mathrm{GJ}$ 前後の小型核融合爆発を炉キャピティ 内で起こす。このとき発生するエネルギーは，中性 子, $\mathrm{X}$ 線,イオンとして放出され，炉第 1 壁にパルス 負荷を与える。このパルスエネルギーはブランケッ トで熱エネルギーに変換され，電力として取り出さ れる。慣性核融合炉の特徽は，エネルギードライバ 一とその入射系とパルス出力を受ける炉第 1 壁にあ る。現在までに提案された炉概念はこれらの要素の 特性で分類される。

1970 年代後半に高エネルギー利得を実現するた めの方策が定まり，それとともに慣性核融合炉の 種々の概念が提案されてきた。大別すると、レーザ 一核融合炉と軽抢よび重イオンビーム核融合炉に区

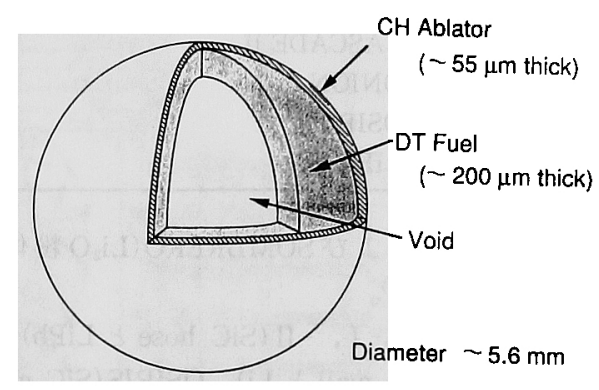

第 V-4 图核蝔合炉用高利得ターゲットの構造図

別される。第 V-1 表にまとめるように, 炉型式は， さらに炬チャンバ第 1 壁の種類により区別される。 すなわち，第 V- 1 表の概念は，

(1) Jet, Water fall

(2) Wetted wall, Wetted hose

(3) Rotating wall

(4) Ablation tile wall

(5) Z 数の高いガス・磁気シールド

のいずれかの方式を取っている。(1) (3)の方式は $\mathrm{LiPb}, \mathrm{FLiBe}, \mathrm{Li}$ 等の液体金属もしくは $\mathrm{Li}_{2} \mathrm{O}$ の粉 体を第 1 壁として用いたものである。

(1)は, HYLIFE-I(Water fall), HYLIFE-II (Liquid Li-jet), SENRI-I, II (Water fall), HIBLIC 
第 V-1 表 慣性核融合炉の概念設計一筧

\begin{tabular}{cllll}
\hline \multicolumn{1}{c}{ レーザー炉 } & & & \\
1977 & SOLASE & Laser $(1 \mathrm{MJ} / 20 \mathrm{~Hz})$ & Gain 150 & $\mathrm{Li}{ }_{2} \mathrm{O}$ \\
1978 & Mag. Protected Chamb. & Laser $(? / 2.5 \mathrm{~Hz})$ & Gain? & $\mathrm{Li}$ \\
1978 & HYLIFE-I & KrF $(4.5 \mathrm{MJ} / 1.5 \mathrm{~Hz})$ & Gain 400 & $\mathrm{Li}$ \\
1981 & ICF power plant design study & Laser $(2 \mathrm{MJ} / 10 \mathrm{~Hz})$ & Gain 175 & $\mathrm{Li}$ \\
1981 & Wet wall & & & \\
1982 & SENRI-1 & Laser $(5 \mathrm{MJ} / 1 \mathrm{~Hz})$ & Gain 200 & $\mathrm{Li}$ \\
1983 & Pulse star & Laser $(2 \mathrm{MJ} / 4.3 \mathrm{~Hz})$ & Gain 300 & $\mathrm{LiPb}$ \\
1983 & CASCADEI & KrF $(1.5 \mathrm{MJ} / 5 \mathrm{~Hz})$ & Gain 200 & $\mathrm{BeO} / \mathrm{LiAlO}{ }_{2}$ \\
1983 & SENRI-II & Laser $(7.2 \mathrm{MJ} / 1 \mathrm{MHz})$ & Gain 400 & $\mathrm{Li}$ \\
1986 & SUNBURST & Laser $(4.5 \mathrm{MJ} / 1 \mathrm{~Hz})$ & Gain 400 & $\mathrm{Li}$ \\
1984 & SIRIUS & KrF $(1.3 \mathrm{MJ} / 5.5 \mathrm{~Hz})$ & Gain 100 & $\mathrm{SiC} / \mathrm{Li}$ \\
1989 & STARLIGHT & Laser $(? / 5 \mathrm{~Hz})$ & Gain? & $\mathrm{Li} / \mathrm{Li}{ }_{2} \mathrm{O}$ \\
1991 & SOMBRERO & KrF $(3.4 \mathrm{MJ} / 6.5 \mathrm{~Hz})$ & Gain 118 & $\mathrm{Li}{ }_{2} \mathrm{O}$ \\
\hline 重イオン炉 & & & \\
1981 & HIBALL I & HIB $(4.8 \mathrm{MJ} / 5 \mathrm{~Hz})$ & Gain 83 & $\mathrm{LiPb}$ \\
1984 & HIBALL II & HIB $(5.0 \mathrm{MJ} / 5 \mathrm{~Hz})$ & Gain 83 & $\mathrm{LiPb}$ \\
1984 & HIBLIC-I & HIB $(4 \mathrm{MJ} / 5 \mathrm{~Hz})$ & Gain 100 & $\mathrm{Li}$ \\
1988 & LIBRA & Light ion $(4 \mathrm{MJ} / 3 \mathrm{~Hz})$ & Gain 80 & $\mathrm{LiPb}$ \\
1990 & HYLIFE-II & HIB $(5 \mathrm{MJ} / 7.3 \mathrm{~Hz})$ & Gain 75 & $\mathrm{FLiBe}$ \\
1990 & CASCADE II & HIV $(5 \mathrm{MJ} / 5 \mathrm{~Hz})$ & Gain 75 & $\mathrm{C} / \mathrm{LiAlO}{ }_{2}$ \\
1991 & ONION & Laser $(? / 10 \mathrm{~Hz})$ & Gain? & $\mathrm{VCS} / \mathrm{FLiBe}$ \\
1991 & OSIRIS & HIB $(5 \mathrm{MJ} / 6 \mathrm{~Hz})$ & Gain 73 & $\mathrm{FLiBe}$ \\
1992 & LIFE & HIB $(5 \mathrm{MJ} / 6 \mathrm{~Hz})$ & Gain 80 & $\mathrm{LiPb}$ or FLiBe \\
\hline
\end{tabular}

-I(Water fall) おう び SOMBRERO $\left(\mathrm{Li}_{2} \mathrm{O}\right.$ 粉体流 下)代代表される(4)。

(2)は, HIBALL-I, - II ( $\mathrm{SiC}$ hose と LiPb) ${ }^{(5)}$, Wet wall (Porus wall $\prec \mathrm{Li}$ ), OSIRIS (SiC cloth と FLiBe によるWetted wall)およびLIBRA （LiPbの Wetted wall）に代表される。

(3)は, CASCADE- I , - II ( $\mathrm{BeO} / \mathrm{LiAlO}_{2}$ 粉体回転

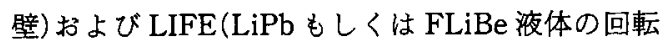
壁)に代表される。

(4)は，取替え可能な $\mathrm{SiC}$ のタイルなどを第 1 壁と するもので大型の炻になる。STARLIGHT(シュラ ウドの利用), SIRIUS(SiCタイル)およ゙ ONION (VCS 壁)が代表的なものである。

(5)は，ガスもしくは磁気により保護する方式で, Mag Protected Chamber (Wet wall との組合せ)が 代表的なものである。

上記(1) (5)の方式のうち, 液体金属を用いる(1) 〜(3)の方式を採用した炉設計が最もよく検討されて おり, 第 1 壁の防護が第一義的に重要な慣性核融合 炉に最も適したものとの共通認識が出来上がりつつ
ある。

大阪大学レーザー核融合研究センターでは，半導 体レーザー励起固体レーザー核融合师「光陽 1 号」の 概念設計を進めつつある。第 V-2 表に炉システムの パラメータを示す。炉チャンバの真空度をレーザー ショット時に $5 \times 10^{-4}$ Torr 以下にする必要がある ため, $3 \mathrm{~Hz}$ 以下の繰返し率となる。一方, 半導体レ ーザー励起固体レーザーでは $12 \mathrm{~Hz}$ の動作が可能 である(6)。したがって,レーザーの建設コストの電力 料金に占める割合を小さくするため，4つのチャン バを 1 台のレーザーで駆動するようにしてある。第 V-5 図がシステム配置である。 チャンバとしては,トリチウム増殖と高エネルギ 一 X 線からの炉壁防御のため, 液体 $\mathrm{Li}_{17} \mathrm{~Pb}_{83}$ を $\mathrm{SiC}$ 織維のパイプに流したものを第 1 壁とした。レーザ 一照射は 32 ビームの球対称照射であり， $30 \mathrm{~m}$ の長 焦点集光鏡により最終ミラーの中性子等による損䅞 を防ぐようにしてある。 $\mathrm{Li}_{17} \mathrm{~Pb}_{89}$ 液体流をガイドす る $\mathrm{SiC}$ 織維のパイプは中性子の重照射を受けるた め，数年で取り変えることが必要である。そのため 
第V-2 表 レーザー核融合発電所「光陽 1 号」のパラメータ

\begin{tabular}{|c|c|c|c|}
\hline \multicolumn{2}{|l|}{ レーザーパラメータ } & \multicolumn{2}{|l|}{ 出 力 } \\
\hline レーザーパルスエルギー & $4 \mathrm{MJ} /$ shot & ペレット利得 & 150 \\
\hline 繰り返し率 & $12 \mathrm{~Hz}$ & 核融合出力 & \\
\hline ビーム数 & 32 & 中性子 & $400 \mathrm{MJ} / 1,200 \mathrm{MW} /$ module \\
\hline 奻 率 & $12 \%$ & X 線＋荷電粒子 & $200 \mathrm{MJ} / 600 \mathrm{MW} /$ module \\
\hline 集光鏡焦点距離 & $30 \mathrm{~m}$ & 合 計 & $600 \mathrm{MJ} / 1,800 \mathrm{MW} /$ module \\
\hline \multicolumn{2}{|l|}{ 反応炬パラメータ } & & \\
\hline 炉半径（内径） & $4 \mathrm{~m}$ & 熱出力 (ブランケット利得 1.1) & $1,980 \mathrm{MW} \times 4=7,920 \mathrm{MW}$ \\
\hline 炉半径 (外径) & $5.5 \mathrm{~m}$ & 電気出力 & $792 \mathrm{MW} \times 4=3,168 \mathrm{MW}$ \\
\hline 第 1 壁厚み & $1 \mathrm{~m}$ & ドライバー電力 & $400 \mathrm{MW}$ \\
\hline 高 さ & $20 \mathrm{~m}$ & 冷却材ポンプ電力 & $30 \mathrm{MW} \times 4=120 \mathrm{MW}$ \\
\hline 繰返し & $3 \mathrm{~Hz}$ & 正味電気出力 & $2,648 \mathrm{MW}$ \\
\hline 基数（モジュール数） & 4 & プラント効率 & $34 \%$ \\
\hline
\end{tabular}

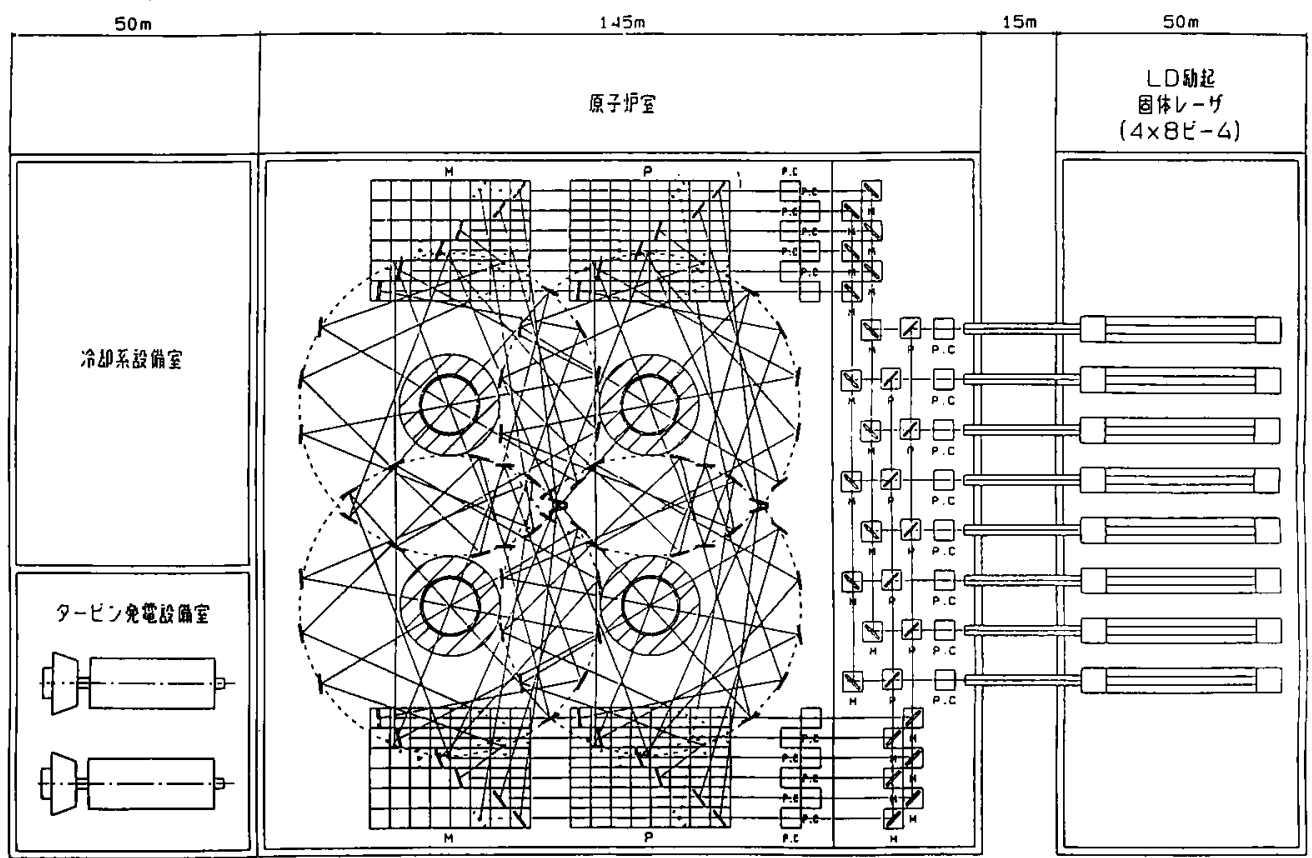

第V-5図 レーザー核融合発電炉システム配置の一例

に，チャンバの上蓋を取り外す構造にしてある。チ ヤンバの縦断面図を第V-6図に示す。

\section{4.まとめ}

大阪大学では，炉心プラズマ研究の成果に立脚し て, 慣性核融合炉発電システム「光陽 1 号」の概念設 計を行なった。炉型式については，過去の方式をレ
ビューし, $\mathrm{SiC}$ 繊維パイプガイドの $\mathrm{LiPb}$ 液体壁を 採用している。炬心プラズマは現状の爆縮データよ り，4MJ のレーザー入射で利得 150 を仮定してい る。

以上の炉設計作業により, 今後の慣性核融合研究 開発のシナリオがより明確になるものと期待され る。 


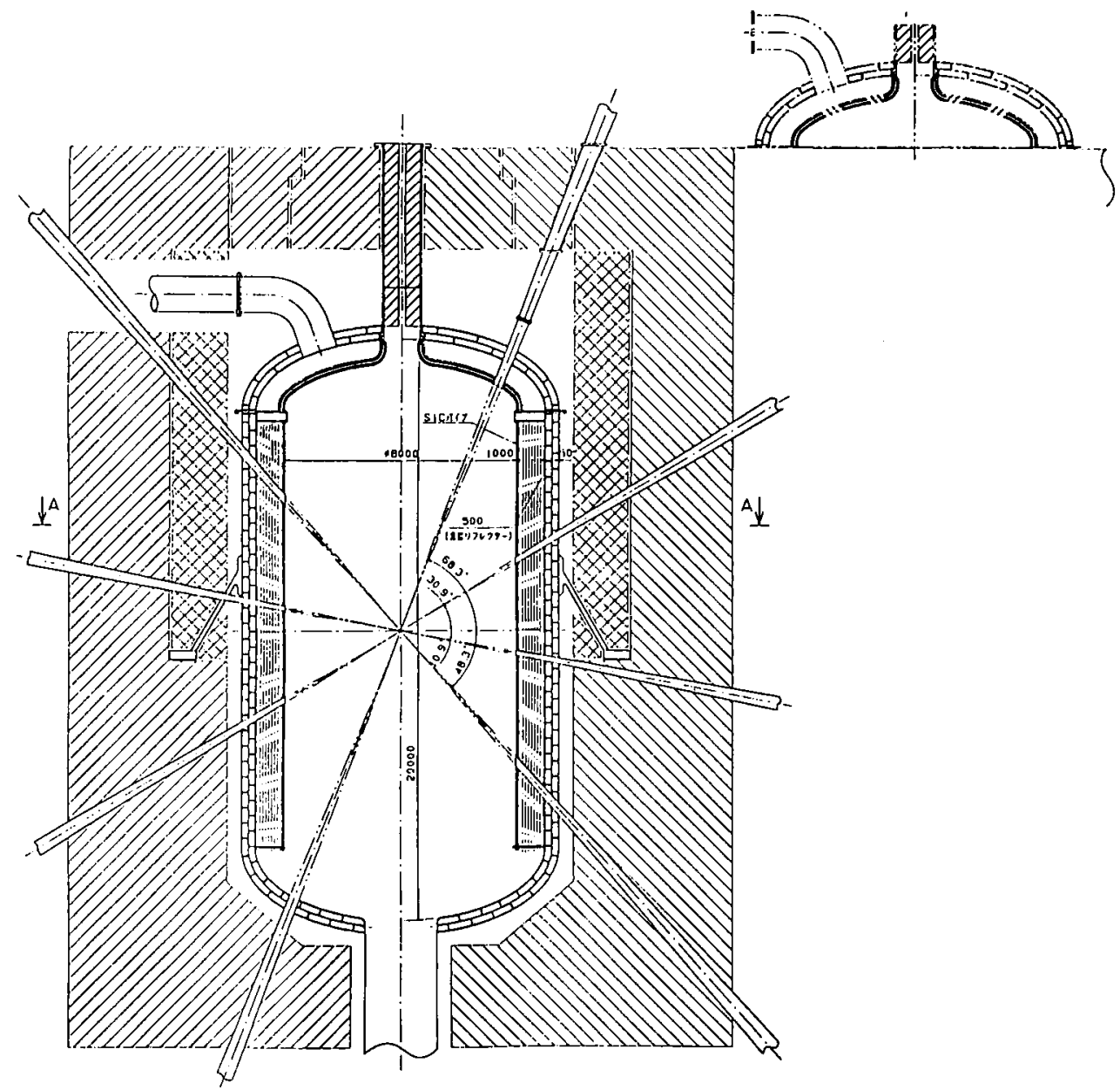

第V-6 図 炉チャンバおよび周囲の構造の緃断面図

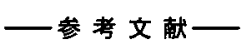

(1) NAKaI, S., et al. : Proc. 13th Int. Conf. on Plasma Physics and Nuclecr Fusion Research, Washington D. C., USA, Oct. $1 \sim 6$ (1990), IAEA.

(2) ZE, F.: UCRL-50021-84, 5 35 (1985).

(3) MCCRoRY, R., et al. : Nature, 335, 225 (1988).
（4）例えば，慣性閉じ込め核融合炉設計検討報告意，大阪大学

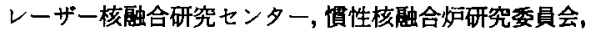
昭和 54 年 3 月。

(5) 例えば, HIBALL-A conceptual heavy ion beam driven fusion reactor study, $K J K 3202, U W F D M-450$, Vols. 1, 2, (1981).

(6) NaIto, K., et al.: Jpn. J. Appl. Phys., 31, 259 (1992). 


\section{VI. 核融合-核分裂 ハイブリッド炉} 三菱原子力工業俶 浅 見 直人

\section{1. 核融合反応と余剩中性子}

現在，研究開発が推進されている核融合炉は，下 記の核反応によるものであり，核融合反応による中 性子をいか利用するかは，核融合炉システムの実 用化シナリオを構築する上で重要な課題である。

(1) $\mathrm{D}+\mathrm{T} \longrightarrow{ }^{4} \mathrm{He}(3.52 \mathrm{MeV})+n(14.1 \mathrm{MeV})$

(2) $\mathrm{D}+\mathrm{D} \longrightarrow{ }^{3} \mathrm{He}(0.82 \mathrm{MeV})+n(2.45 \mathrm{MeV})$

(3) $\mathrm{D}+\mathrm{D} \longrightarrow{ }^{3} \mathrm{~T}(1.01 \mathrm{MeV})+p(3.03 \mathrm{MeV})$

(4) $\mathrm{D}+{ }^{3} \mathrm{He} \longrightarrow{ }^{4} \mathrm{He}(3.67 \mathrm{MeV})+p(14.7 \mathrm{MeV})$

D-T 炉では，核融合反応のエネルギーの約 $80 \%$ は $14.1 \mathrm{MeV}$ 中性子が持って出てくる(1)の反応が主 体であり，(2)，(3)は 2 次的，(4)は 3 次的反応である。

核融合発電炉では，この高エネルギー中性子はブ ランケット中で熱化されるとともに, Li と次の反応 を起こして，燃料物質であるトリチウム $(\mathrm{T})$ を生産 する。

第VI-1 表 核融合と核分裂の中性子バランス比較表 (中性子量は出力 $1,000 \mathrm{MWt}$ の炉として算出)

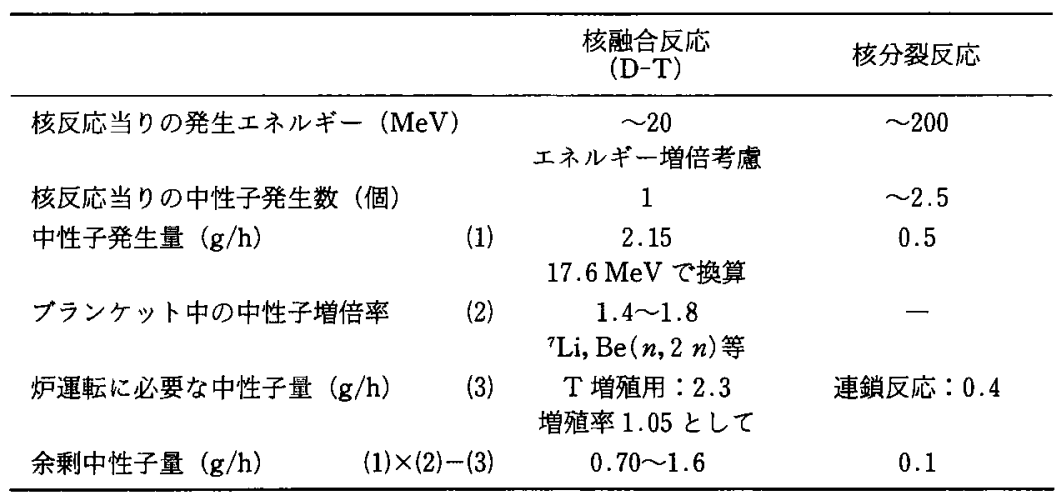

\section{2. 中性子の利用と核融合-核分裂 ハイブリッド炉}

上述した余剩中性子を有効に利用できれば，核融 合開発の付加価值は増大するということができよ う。いいかえれば，核融合炉は余剩中性子源として 考えることができるわけで，この中性子の持つ核的 な特性を生かして活用することで，核融合炉システ ムの開発は, 単に発電炉としての利用以外に多くの 発推進すべきであろう。 のが挙げられている。

（3）放射性廃棄物消滅処理

(4) 各種放射線処理
(5) ${ }^{6} \mathrm{Li}+n \longrightarrow{ }^{4} \mathrm{He}+\mathrm{T}+4.8 \mathrm{MeV}$

(6) ${ }^{7} \mathrm{Li}+n \longrightarrow n^{\prime}+{ }^{4} \mathrm{He}+\mathrm{T}-2.6 \mathrm{MeV}$

核融合中性子は, (5),(6)の両反応により, T 增殖率と して1以上が可能となり，核融合燃料サイクルが自 己完結できることになる。原理的には，T増殖率は 1 を確保できる中性子量があればよく，それ以上の 中性子は余剩中性子と呼ぶことができる。

一方， D-D 哣では(2)，(3)の反応が約半々の割合て 起き，(1),(4)が 2 次的に起きる。したがって，D-D 炉 では T增殖を行う必要がなく,すべて余剩中性子と なる。

以下の議論では， D-T 炉について考えることとす る。参考のために，核融合炉と核分裂炉の中性子バ ランスの比較を第VI-1 表に示す。この比較表でもわ かるように，同じ出力の炬心では，核融合炉は核分 裂炉の約 4 倍の中性子を発生し，さらに核骶合ブラ ンケット中の ${ }^{7} \mathrm{Li} の\left(n, n^{\prime}\right)$ 反応や, $\mathrm{Be}$ 等の $(n, 2 n)$ 反応による中性子増倍反応を含めると，余剩中性子 の量は約 1 析多くできる可能性がある。核融合炉が 核分裂炬との比較において，energy poorで，neutron rich といわれる所以である。

可能性を持つものである，との認識の上に立って開

こうした観点での調查研究は, 日(1)(2), 米(3) (7) でな されてきており，活用技術としては，次の上うなも

(1) 核燃料 $\left.{ }^{239} \mathrm{Pu},{ }^{233} \mathrm{U}\right)$ 生産(ハイブリッド炬)

（2）放射性同位元素(RI,含むトリチウム)生産 
（5）水亲等合成化学燃料生産, 等

ここでは，核融合炉の技術開発が原型炉レベルに 達した段階で，1つの核融合炉システムのオプショ ンとして有望視される核融合一核分裂ハイブリッド 炉について概説する。

\section{3. ハイブリッド炉システムの概念}

核融合-核分裂ハイブリッド炉(以下,ハイブリッ ド炉)とは,核融合炉のブランケット部に核燃料物質 を装荷するもので，基本的には核融合炉の基本構成 を持つものである。

ハイブリッド炉はブランケット中に装荷した核分 裂親物質 ${ }^{238} \mathrm{U},{ }^{232} \mathrm{Th}$ ) の中性子捕獲反応(第VI-1 図 参照)による, 核分裂性物質 $\left({ }^{239} \mathrm{Pu},{ }^{233} \mathrm{U}\right)$ の生産を主 として期待する核燃料生産型と，核分裂性物質 $\left.{ }^{(235} \mathrm{U},{ }^{239} \mathrm{Pu},{ }^{233} \mathrm{U}\right)$ によエネルギー増倍を主に期 待する電力生産型とに大別することができる。
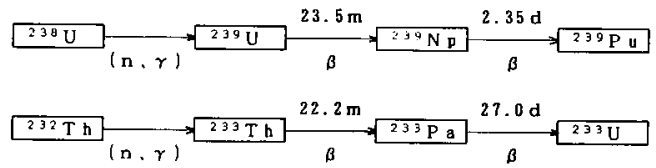

第VI- 1 図 核分裂物質 $\left.{ }^{238} \mathrm{U} \rightarrow{ }^{239} \mathrm{Pu},{ }^{232} \mathrm{Th} \rightarrow{ }^{233} \mathrm{U}\right)$ の生成過程

核燃料生産型ハイブリッド炉は現在の軽水炉を中 心とする原子力発電体系の中に位置づけ，核燃料を ハイブリッド炉で生産し，分裂炉に供給するシステ ムで，軽水炉との共存による核融合炉システムの実 用化を狙ったものである。

後に述べるように，ハイブリッド炉での核燃料生 産能力は核分裂炉に比較して高く，核分裂炬の転換 比が 1 に満たない分を供給するとすれば,多数(例え ば 10 基程度)の核分裂炉に核燃料を供給できる能力 を持っており，複数の核分裂炬との共生を考えたシ ステム概念例として，エネルギー・パーク構想(7)の 提案がある。

一方，電力生産型ハイブリッド炉は比較的低いプ ラズマ炉心条件で, 主として高い電力生産性を租っ たもので, 核融合炉の総合的な出力密度の低さを補 うシステムとして提案されている。

前者はブランケット中での分裂反応を極力抑える 方式で，分裂反応抑制型(fission suppressed type) と もいわれ，一般にブランケット中のエネルギー増倍 率を抑え，燃料生産率を高くとる概念である。
また，後者は安全性の観点から，末臨界条件を满 たす範囲で分裂性物質の量を多く装荷し，分裂反応 を起きせ，エネルギー増倍率を高くとる概念であ る。 ${ }^{235} \mathrm{U},{ }^{239} \mathrm{Pu},{ }^{233} \mathrm{U}$ 等の熱中性子による核分裂反応 に主として期待するところから，熱中性子核分裂型 といえる。

さらに, D-T 反応中性子は $14 \mathrm{MeV}$ の高いエネル ギーを持つことから, ${ }^{238} \mathrm{U},{ }^{232} \mathrm{Th}$ 等の親物質でも高 エネルギー分裂反応を起こすので，それによる中性 子増倍とエネルギー発生を利用することも可能であ る。この場合, ${ }^{238} \mathrm{U} や{ }^{232} \mathrm{Th}$ をプラズマに近いとこ ろに装荷することで，その効果を実現できる。この 概念を高速分裂反応型 (fast fission type)と称して いる。

ハイブリッド炉は，どのような概念を重視するか でブランケットの構成が異なり，その意味で設計の 自由度が高いともいえよう。以上述べたハイブリッ ド炉の炉型概念とブランケット方式を分類してみる と第VI-2図(1)のようになる。

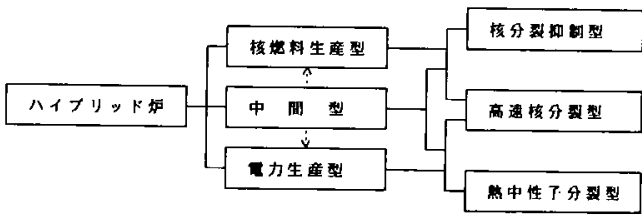

第VI- 2 図 ハイブリッド炉型と主なブランケット 方式の関係

\section{4. ハイブリッド炉のブランケット}

\section{概念検討例}

核融合発電炉のブランケットの主要な機能は，(1) D-T 中性子の熱化と除熱，(2) $\mathrm{Li}-n$ 反応による核殷 合燃料トリチウムの生産, (3)中性子遮蔽である。ハイ ブリッド笹ではこれに，(4)中性子増倍，(5)核燃料物質 の生産, (6)核分裂反応によるエネルギー増倍の機能 が加わる。

ハイブリッド炉の概念は古く，これまで多くの設 計検討がなされてきている(1)(7) (9)。前述のように,ブ ランケットの構成・配置等の設計自由度は高いので, 設計例に見られる概念も様々である。ここでは，八 イブリッドブランケットの検討例を上述の議論との 対比で，わかり易く整理した特性比較表を第 VI-2 表(1)(10)に示す。 
第VI-2 表 ハイブリット炉のブランケット特性比較(1)(10)

\begin{tabular}{|c|c|c|c|c|c|c|c|c|}
\hline 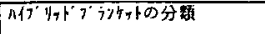 & 然中性子 & \multicolumn{3}{|c|}{ 高寀接分型型 } & \multicolumn{4}{|c|}{ 核芴裂抑制型 } \\
\hline 柜の主たん目的 & 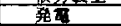 & 烧育 & 甡西然料生商 & 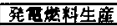 & 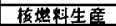 & 器㘰生公実证 & 寉整料生磁 & 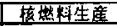 \\
\hline 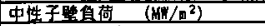 & 1.0 & 0.87 & 1.0 & 1.9 & 1.0 & 1.08 & 1.0 & 3.4 \\
\hline ブランケット棈成 & 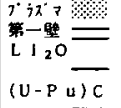 & 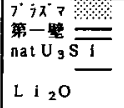 & 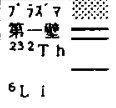 & 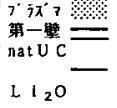 & 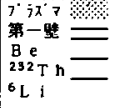 & 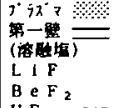 & 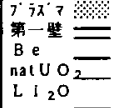 & 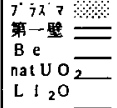 \\
\hline 制料サイクル & ${ }^{230} \mathrm{U}-239 \mathrm{Pu}$ & ${ }^{298} \mathrm{U}-{ }^{299} \mathrm{Pu}$ & ${ }^{232} \mathrm{Th}^{259} \mathrm{~V}$ & ${ }^{238} \mathrm{U}-{ }^{299} \mathrm{Pu}$ & ${ }^{292} \mathrm{Th}-{ }^{233} \mathrm{U}$ & $290 \mathrm{U}-299 \mathrm{Pu}$ & ${ }^{296} \mathrm{U}-299 \mathrm{Pu}$ & ${ }^{298} \mathrm{U}-{ }^{259} \mathrm{Pu}$ \\
\hline 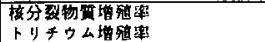 & $\begin{array}{l}0.14 \sim 0.105 \\
1.11(\mathrm{BOL})\end{array}$ & $\begin{array}{c}\sim 0 . \overline{75} \\
1.04(\mathrm{BOL})\end{array}$ & $\begin{array}{l}0.83 \\
1.00\end{array}$ & $\begin{array}{l}0.86 \\
1.05\end{array}$ & $\begin{array}{l}0.82 \\
1.05\end{array}$ & $\begin{array}{l}0.42 \\
1.05\end{array}$ & $\begin{array}{l}0.48 \\
1.09\end{array}$ & $\begin{array}{l}0.7 \\
1.05\end{array}$ \\
\hline 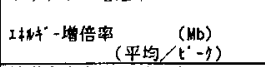 & $\begin{array}{ll}1.19 & \text { (EOL) } \\
7.90 & \text { (BOL) } \\
8.17 & \text { (EOL) } \\
\end{array}$ & $\begin{array}{l}1.16 \text { (EOL) } \\
4.67 \text { (BOL) } \\
6.49 \text { (EOL) }\end{array}$ & $\sim 5.2$ & 6.4 & 1.6 & 2.2 & 1.57 & 2. 3 \\
\hline 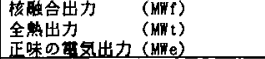 & $\begin{array}{r}2786 \\
729 \\
\end{array}$ & $\begin{array}{c}668 \\
2368 \sim 3240 \\
\sim 1000 \\
\end{array}$ & $\begin{array}{c}810 \\
-4000 \\
740\end{array}$ & $\begin{array}{r}697 \\
3009 \\
\sim \\
\sim 1200\end{array}$ & $\begin{array}{r}2100 \\
\sim 4000 \\
720\end{array}$ & $\begin{array}{r}850 \\
1400 \\
490 \\
\end{array}$ & $\begin{array}{r}370 \\
418 \\
0\end{array}$ & $\begin{array}{r}1670 \\
, \quad 3070 \\
\sim 1200 \\
\end{array}$ \\
\hline 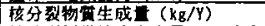 & - & $\sim 1500$ & 2900 & 1950 & 5200 & 960 & 690 & 3900 \\
\hline 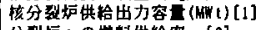 & 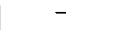 & 10500 & 29900 & 13700 & 53600 & 6760 & 4860 & 27400 \\
\hline 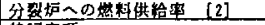 & - & 3.8 & 7.5 & 1.6 & 13.1 & 4.8 & 11.6 & 8. 9 \\
\hline 特梩事項 & 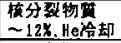 & 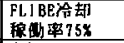 & $\begin{array}{c}\text { 最大出力密度 } \\
800 / \mathrm{cc}\end{array}$ & 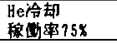 & 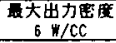 & 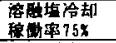 & 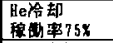 & 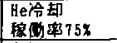 \\
\hline 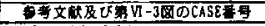 & (1) & (1), CASEX15A & $(10)$ & (1) & $(10)$ & (1) & (1) & (1).CASEX14A \\
\hline
\end{tabular}

\section{5. ハイプリッド炉の導入効果}

軽水炉等と共存させてハイブリッド炉を導入する ことにより，長期の天然 Uの節約がどの程度可能で あるかの検討解析が行われており(2)(11)，ここでは国 内の試算例(2)を第VI-3 図に示す。CASE-Y11 は在 来から考えられている組合せで, FBR 導入までは天 然U 燃焼の ALWR を建設し，軽水炉で生産される Puは，もっぱら FBR 道入に備えて蓄積しておき， 2030 年以降 FBR を導入し，天然Uを節約する。 CASE-X14A，X14B，X15A は FBR の代わりにハ
イブリッド炉て $\mathrm{Pu}$ を生産し，天然 U を節約する場 合である。この場合，Pu燃焼の LWR 1993 年に 導入し,2000年には, 高転換軽水炉を導入して LWR で出来た Pu を燃料として使用し，2030 年にハイブ リッド炉を導入して $\mathrm{Pu}$ 生産を行い, 一層の天然 U の節約を図るシナリオである。CASE-X14A は燃料 生産型で天然 U, CASE-X14B は燃料生産型で隇損 U, CASE-X15A は電力生産型で天然 Uを用いる八 イブリッド炉を導入した場合である。

比較してわかるように，ハイブリッド炉導入によ る天然Uの節約量は大変顕著であり,ハイブリッド

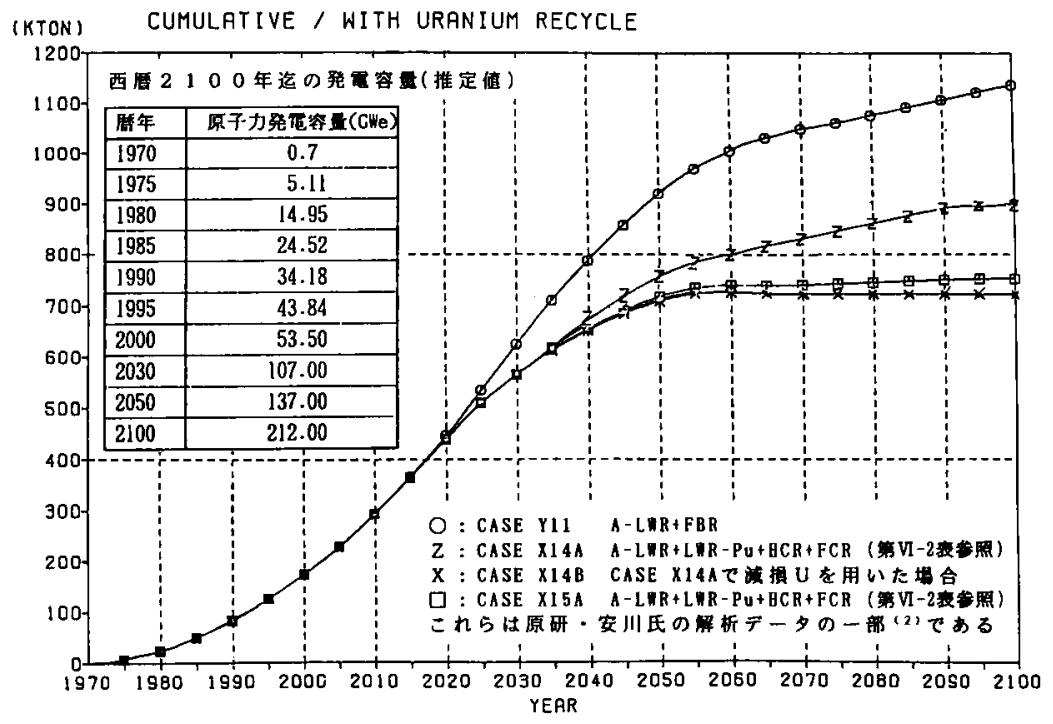

第V-3図ハイブリッド炉導入による天然U 樌算需要量への奻果(2) 
炉に天然 Uを用いる場合は，天然 Uの累積所要量 は漸增するが, 減損 Uを用いればハイブリッド炉道 入後約 20 年で, 天然Uの新規購入量はほとんどゼ ロになる。FBR 迺入の CASE-Y11に比較して, 累 積天然 Uの必要量は 2100 年までに約 $400 \mathrm{kt}$ 節約 される計算になる。

\section{6. ハイブリッド炉の評価と課題}

\section{（1）経斉性}

ハイブリッド炉の経済性については幾つかの解析 例(1)(3)(6) があるが，様々な不確定要素や仮定が含ま れるので，現段階で絶対的な評価より，相対的評価 の方が重要であろう。その意味で, 発電コストを軽 水炉, 核融合発電炉,ハイブリッド炉で比較した我が 国の計算例(1)(12)(13) によると,ハイブリッド炉は軽水 炉の 1.4 倍, 核融合発電炉の約 $80 \%$ との試算例があ る。また, ハイブリッド炉の利点の一つは, ドライ バとなる核融合炉の要求性能を低くでき, 発電原価 を 15 円 $/ \mathrm{kWh}$ (軽水炉の約 1.3 倍)にするのに，核融 合発電炉に比較してプラズマ $\beta$ 值で $2 / 3$, 中性子 壁 負荷で $1 / 3$ 程度(1)でよい。

\section{(2) 安全性}

ハイブリッド炉では，ブランケットに装荷あるい は生成される分裂性燃料の圕を臨界末満の条件を満 たすように設定できるので，いわゆる反応度事故は 起きない。次に放射性物質のインベントリーについ ては，八イブリッド炉では，核分裂生成物の量, 燃料 物質の量もかなり多くなり，相対的毒性度の比較(14) で，特に電力生産型のものは行裂炉に近い値を示 している。これを下げるには，分裂反応抑制型とし， 溶融塩炉にしてそれらの量を制御する方法も考えら れる(15)。

また，LOCA 時の安全性については，電力生産型 では十分な対策が必要であろう。いずれにせよ，核 融合炉の安全性の問題に，核分裂炉の放射性物質の 安全性に関する問題を重複させることになるので, 核融合発電炉に比べて環境面, 安全面,核㹡散面で配 慮すべきことは格段に多くなる。

\section{(3) 開発課題}

ハイブリッド炉は核融合発電炉の実用化開発過程 の比較的初期の段階(原型炉クラスの炉心技術)で, 現在のエネルギーシステムとの共存の形で取り込み 得る可能性を持つシステムである。前述のように， その導入と設計の思想により，ハイプリッド炉の設
計自由度は大きいので，当面の課題として，以下の エネルギーシステムとしての導入効果と設計・評価 検討を十分に詰め，開発目標を絞り込んで行く必要 があろう。

(1) ハイブリッド炉導入による原子カシステム への影響評価と導入シナリオの最適化

(2) 分裂炉の燃料サイクルコストと発電コスト に与えるハイブリッド炉㙛入効果の解析評価

(3) 導入シナリオに適合するハイブリッドブラ ンケットの最適設計

（4）実現性の高い(保守性, 安全性, 経昘性に優 れた)ハイブリッド弱設計と語価

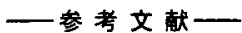

(1) 原産：「核融合反応の多角的利用を目指して」昭 62 年度原 研委託調监，「核融合反応の活用技術に関する調査」報告 害, (昭 63.3)。

(2) 原子力学会 $\lceil\mathrm{FNT} \backslash$ 研究尃門委：中性子利用ワーキングタ ループ報告書, (1989).

(3) SchLTZ, K.R., et al.: "The fusion application study (FAME), Fusion Technol., 10, 1279 (1986).

(4) OTA. STARPOWER : The U.S. and the International Quest for Fusion Energy, App. A-Non Electric Application of Fusion, 201 (1987)

(5) Committee on Fusion Hybrid Reactors (NRC) : Outlook for the Fusion Hybrid and Tritium-Breeding Fusion Reactors, (1987).

(6) Holden, J.P., et al. : Summary of Report of Senior Committee on environmental, safety, and economic aspects of magnetic fusion energy (ESECOM), UCRL -53766-Summary, (1987).

(7) Maniscalco, J.A., et al. : Recent progress in fusionfission reactor design studies, Nucl. Tech./Fusion, 1419 (1981).

(8) MOIR, R.W. : The fusion breeder, J. Fusion Energy, 2 351 (1982).

（9）原子力学会研究専門委編：“核融合炉設計及び研究開発の 現状と問題”，IX-2, 400 (1983).

(10) ManiscalCo, J.A., et al.: The fusion breeder-An early application of nuclear fusion, Fusion Technol., 6, 584 (1984)

(11) AMHERD, N.A. : A summary of EPRI's fusion-fission hybrid evaluation activities, $J$. Fusion Energy, 2, 369 (1982).

(12）電中研報告「21 世紀経済社会の展望とエネルギー・電力供 給」, 143 (1985).

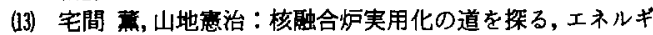
$-, 20(5), 18$ (1987).

(14) WOLKENHAUER, W.C., et al. : Safety study on hybrid reactor, CONF-740402-P1, (1974)：BNWL-SA-4988, (1974).

(15) INOUE, M., et al. : Conceptual design of demonstration molten salt hybrid reactor (DMHR), Proc. 4th Int. Conf. on Emerging Nuclear Energy System, Madrid, (1987). 


\section{VII. 核融合ロケット}

九州大学総合理工学研究科 中 島 秀 紀

米国ては, SEI (Space Exploration Initiative : 宇 宙探查構想)プロジェクトのもと，2010 年代に有人 火星飛行を行う計画がある。人類が地球圈外へ進出 し定住することは, 現在の地球の環境悪化,有限な資 源，増大する人口等を考えれば，必然の上うに思え る。しかしながら，現在の化学ロケットで，近い 将来その火星に基地や居住地を建設するために必要 な何 $100 t も の$ 資材等を運搬するには適していな い。

高性能のロケットには,高い「比推力」と大きい「比 出力」を同時に満足させることが要求される。「比推 力」は，燃料の燃焼によって生み出される推力を燃料 の流量比で割ったものとして定義され，それは燃料 の排出速度に比例したものとなる。比推力が高けれ ば，それだけ燃料が有効に使われることになる。一 方,「比出力」は，ロケットの出力をプラント総質量 で割ったもので定義される。プラント質量あたりの 推力は「比出力」に比例するので, この值が大きいこ とは軽い強力なエンジンを意味する。第VII-1 図に 「比推力」と「比出力」との関係を示す。図の右上に位 置するロケットが性能が優れていることになる。化 学ロケットは大量の推進材を低い排出速度で排出す

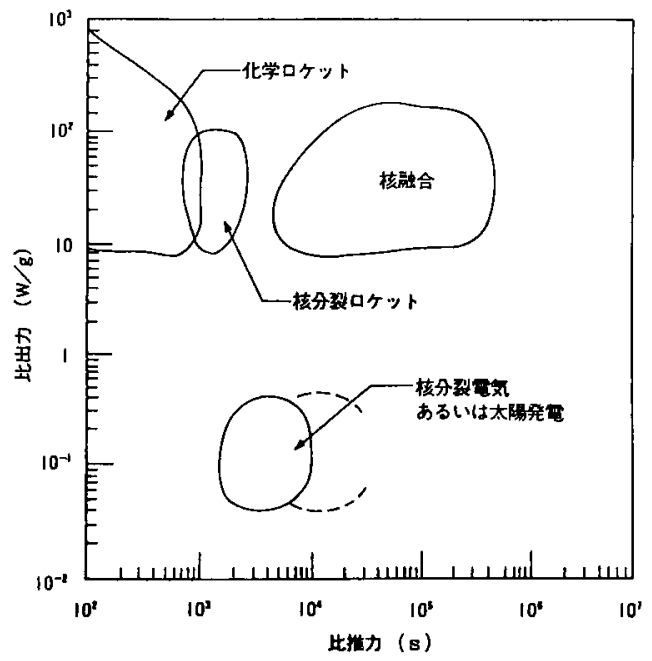

第VII-1図 各種ロケットの性能比較
るために推力，すなわち比出力は大きいが，比推力 は小さい。電気推進ロケットでは，太陽や原子炉を 利用して発電しイオン等を高速に加速するために， 排出速度，すなわち比推力は大きくなるが，推力自 身は極めて小さい。したがって，目的地までに長い 航行時間が要求される。

核分裂ロケットは比出力は高いものがとれるが， 冷却材を兼ねる推進材の排出速度は原子炉容器の融 点などの制約のためあまり高くとれない。したがっ て比推力は大きくならない。核融合ロケットでは, 核融合反応で生じた高速のプラズマ粒子を磁場を介 して直接推力へ変換するので, 材料の融点といった 制約がなく，高い排出速度，すなわち大きな比推力 が得られる。

近未来の技術を考えれば，高い「比推力」と大きな 「比出力」を同時に満足させるものは核融合ロケット しかない。

核融合反応を生じさせる方式としては「磁場閉じ 込め」と「慣性閉じ込め」の 2 つがある。最終的にどち らの方式が有利かを決定するためには，それぞれの 方式による詳細設計を行い,比較・検討が今後必要て ある。

磁場閉じ込め方式では，強力な磁場によりプラズ マを囲む形で閉じ込める。したがって，磁場発生用 のコイルは，核融合プラズマで発生する中性子の照 射を受けるので，重い遮蔽体，また遮蔽体に落ちた 中性子のエネルギーを搭てるために重い排熱装置が 必要となる。ロケット応用を考えるときは，中性子 発生量の多いDT 核融合反応は候補となりえず, $\mathrm{DD}, \mathrm{D}^{-3} \mathrm{He}$ 反応等の中性子発生量の少ない，いわゆ るアドバンスト燃料核融合が利用されるであるう が,そのためには，DTよりさらに困難なプラズマ閉 じ込め技術が要求される。

その磁場閉じ込め方式では，開放端系が適してお り，従来まてにに，タンデムミラー(1)，磁場反転配位 $(\mathrm{FRC})^{(2)}$ ，双極子磁場(3) に基づく核融合ロケットが 提案されている。いずれも $\mathrm{D}^{-3} \mathrm{He}$ 燃料の使用を想定 している。これらの方式では, シンクロトロン輻射損 失を小さくするための高 $\beta$ 化が可能であり，また荷 電粒子の開放端への流れを利用して推力を得ること ができる。特に最近では FRCが有望視されてい る(4)。第VII-2 図に, FRC ロケットの概念図を示す。 推力増強のために推進材(主に水素)が加えられる。 それは，漏れ出す核融合プラズマと混合し，磁気， 
ズルを通して排出される。FRCについては第IV章を 参照のこと。地上用炉では, DTトカマク炉が今は全 盛であるが，この“鉄のかたまり”はロケットに向か ない。しかし，現在のところはトカマク方式以外に 大型計画はない。

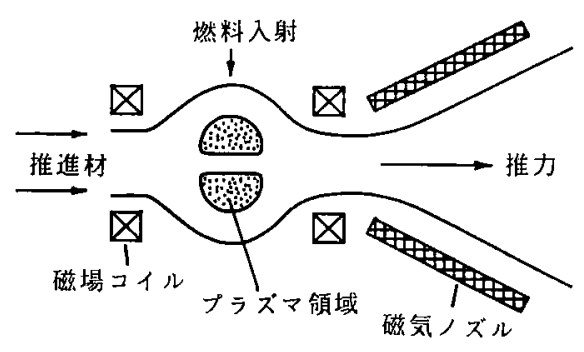

第VII- 2 図 FRCロケット概念図

慣性核融合ロケットでは, 数 MJ のレーザーまた は粒子ビームが燃料ペレットを圧縮・高温化し核融 合反応を生じさせる。個々のペレットの大きさは直 径 $1 \mathrm{~cm}$ 程度であるが, 爆発すると TNT 火薬数 $\mathrm{t}$ 分 に相当するエネルギーを発生する。このミ二爆発を 連続して(例えば毎秒 30 回) 起こし, 爆発で生じた高 速のプラズマを磁場によって反射してやれば宇宙船 を押し出す推力を生み出される。

慣性核融合ロクットでは，核融合によって発生す る中性子の照射を受ける面積を小さくすることがで
きる。このため, DT 燃料の使用可能性がある。むし ろ, 燃料選択の際のメリットの指標となるものは, (ペレットゲイン) $\times$ (荷電粒子割合)である。ここで, ペレットゲインは核融合出力とドライバ入力エネル ギーの比で定義される。DTでは，荷電粒子の割合 は， $\mathrm{D}^{-3} \mathrm{He}$ に比べて小さいが, ペレットゲインは大 きくとることができるので，結果的にはこの指標を 大きくすることができる。DT燃料を採用するレー ザー核融合ロケット「ヴィスタ」が設計されてい る(5)。第VII-3 図に，ヴィスタの概観図を示す。 形状は, 内側が空っぽの円錐形, いわば “ちゃわ ん”型であり，中性子昭射を受ける面積を最少にし ている。レーザー本体等の機器や搭乗員室などをコ イル・シールドの影の部分，才なわちシールド後方 の“ちゃわん側面”にあたる場所に置く工夫がしてあ る。この宇宙船の性能としては, 比推力 $17,000 \mathrm{~s}$, 比 出力 $18 \mathrm{~W} / \mathrm{g}$ である。また, $5 \sim 10$ 人の搭乗員と 100 $\mathrm{t}$ の積荷を乗せ，10日間の火星滞在期間も含めて 100 日間で火星往復が可能というものである。(化学 ロケットでは, 22 ヶ月上をかけて火星往復を行う シナリオが発表されている。)

核融合ロケットの可能性について議論してきた が，実現化には解決すべき幾多の課題がある。しか し, 軽量化が要求されることを除けば，地上用に開 発された技術は，そのまま宇宙用に役立つものが多 い。核融合ロケットがもたらす計り知れない恩恵を

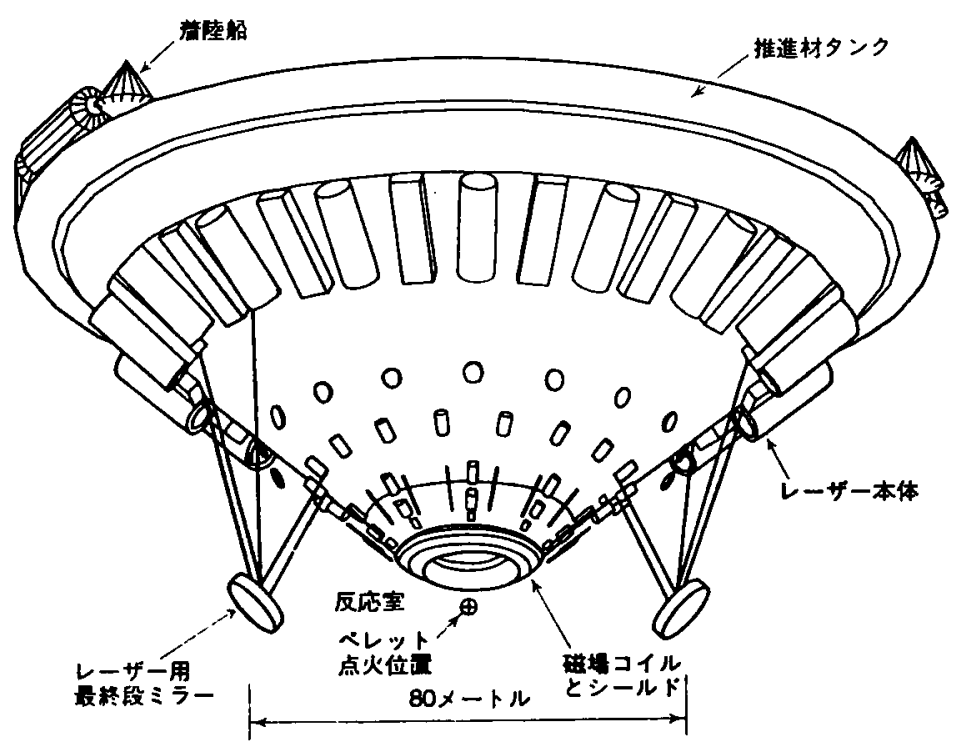

第VII-3 図 ヴィスタ宇宙船の概観 
考えると，今後の更なる研究が望まれる。特に磁場 閉じ込め方式ではそうであるが，ロケットに応用て きる方式は研究のメインラインにはない。しかし， その将来性を考えるとき，DTトカマク炉以外のこ れらの方式についても研究を続けておく必要があ る。

\section{VIII. ミュオン触媒核融合,} 常温核融合など

\section{東京大学理学部・永 嶺 謙忠}

1989 年に起こった「常温核融合」騒ぎをきっかけ として,ミュオン触媒核融合(Muon Catalyzed Fusion： $\mu \mathrm{CF}$ )が注目されるようになった。この $\mu \mathrm{CF}$ は，中間子の存在が予言された 1940 年代から 提案され基礎研究が今日まで進行していて，高温を 必要としない低温核融合の元祖と考兄るべきもので ある。

詳細は別の解説(1)(2) にゆずるとして, D-T 系ミュ

\section{一參考文献一}

(1) SANTARIUS, J.F.: Proc. Minicourse on Fusion Applica tion in Space, Salt Lake City, Utah, 1988, p 241.

(2) Chapman, R., et al. : Fusion Technol., 15, 1154 (1989).

(3) 長谷川晃: パリティ, 7, 42 (1992).

(4) SCHULZE, N.R. : NASA TM-4298, (1991).

(5) ORTH, C., et al. : UCRL-96832, (1987).

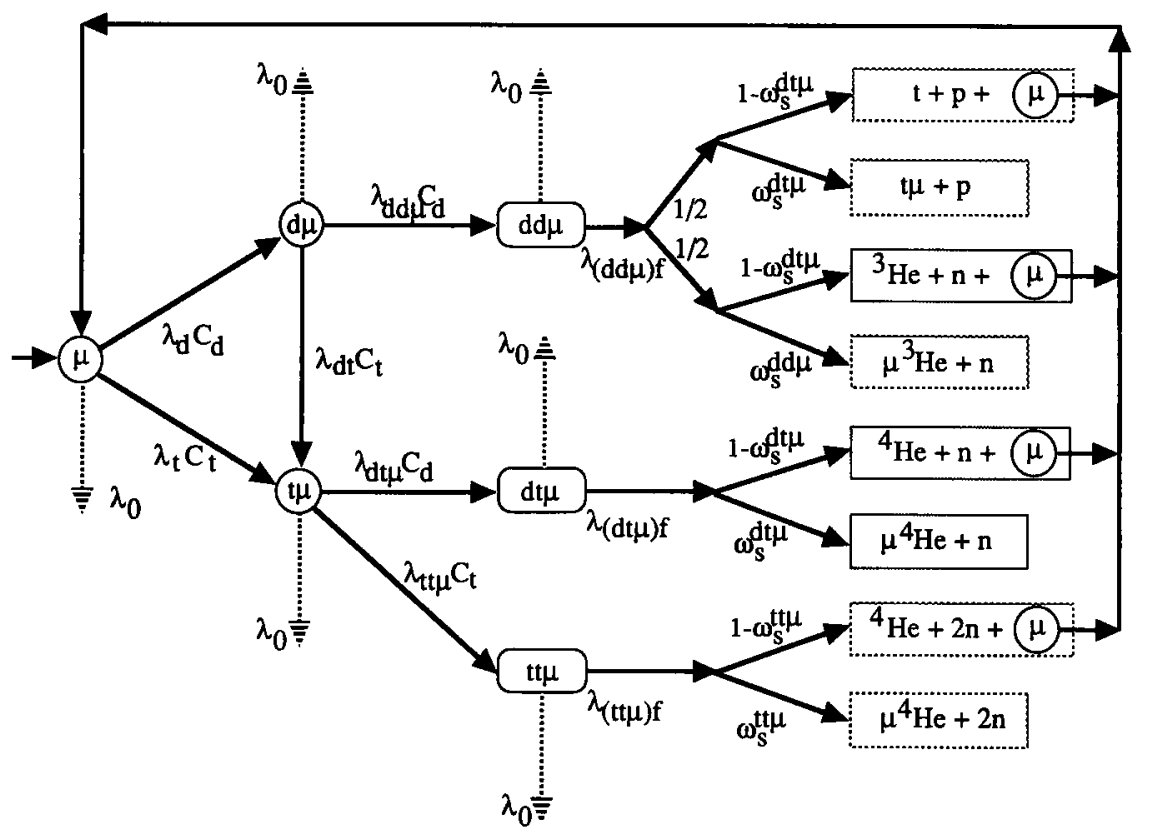

$\lambda_{0}$ はミュオンの崩壤率，他の $\lambda$ は規格化密度が 1 の時の反応率を表わす。C $C_{t}, C_{d}$ はそれそれ 三重水素と重水索の成分比率， $\omega_{s}$ はそれそれの核淈合反応におけるミュオン付着率を表わす。

第VIII-1図ミュオンDT 触媒核骶合サイクル 
( $d t \mu)$ という形の分子状態を作ることが期待され る。この $(d t \mu)$ の分子状態に $0.6 \mathrm{eV} も の$ 浅い準位が あり，その準位からのミュオン分子生成と $\mathrm{D}_{2}, \mathrm{DT}$ 分子の電子状態の励起とが共鳴する形で，急速にミ ュオン分子が生成される。この反応の速さは実験的 に調べられていて，系の密度掞よび温度に依存する。 液体水素密度に近い高密度 $\mathrm{D}_{2} / \mathrm{T}_{2}$ 中では, $10^{-8} \mathrm{~s}$ 以 下の速さである。この共鳴的分子生成による理論で は D-T 系の実験結果を定量的に説明することがで きていない。

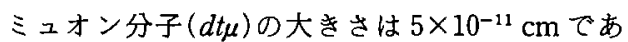
り, 分子振動やトンネル効果の助けを借り, 分子内 で核融合が急速に起こり，中性子と $\alpha$ 粒子 $(\alpha)$ とが

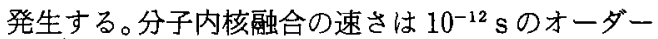
である。核融合反応を起こした後，ミュオンは再び 自由になり，次々と連鎖的に核融合を起こしてゅく。

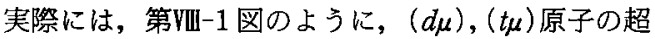
微細分離の効果や，反応生成物である ${ }^{4} \mathrm{He}$ への移行 反応などを考慮する必要がある。ミュオンの寿命 $2.2 \mu \mathrm{s}$ の間に何回核融合が起こるかは, 融合反応後 に生まれる $\alpha$ 粒子にミュオンが付着して $(\alpha \mu)$ とな る割合, 初期 $\alpha$ 付着率 $\left(\omega_{s}\right)$ と $(\alpha \mu)$ イオンが減速中 に分解する割合 $(R)$ とで決まる有効 $\alpha$ 付着率 $\left(\omega_{5}=\right.$

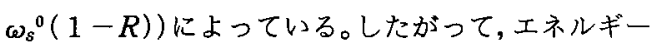
の生産の原理的な限界は $\omega_{s}{ }^{-1} \times 17.6 \mathrm{MeV}$ となる。

この $\alpha$ 率は, 核融合中性子数の絶対数とサイクル 率との比較， $(\alpha \mu)+$ イオンの測定などによって実験 的に求めることができる。高密度 D-T 系 $\mu \mathrm{CF}$ での $\alpha$ 付着現象を $(\alpha \mu)$ からのX 線を直接捉えることに よって調べる実験が，東大-理研-原研のグループに より, 高エネルギー物理学研究所内東京大学中間子 科学研究センターにおいて成功をみた。 $\omega_{s}$ の值とし て 0.34(13)\%が得られている。この $\omega_{s}$ からは, 約 300 回の核融合が起こるはずであるが，実測された 核融合中性子はその半分程度である。D-T 系中の $\mathrm{He}$ 不純物への捕獲, D-T 系の容器壁の効果などの

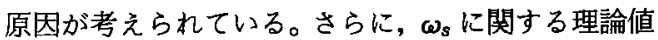
は実験值よりも $50 \%$ 近く大きい。この差は, $(\alpha \mu)$ の 低エネルギー領域での $R$ が異常に大きいためでは ないかと考えられている。

的が決まると $\mu \mathrm{CF}$ によるエネルギー生産の上限 が決まる。一方, $1 \mathrm{GeV}$ 程度の重水素ビームを $\mathrm{Li}$, $\mathrm{Be}$ などの軽核にぶつけ,生ずるパイオンをできるだ け集めそれを $\mu^{-}$にかえることにより，1個の $\mu^{-}$を
得るには $5 \mathrm{GeV}$ のエネルギーが必要となる。したが

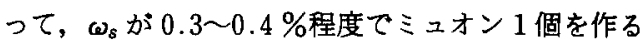
エネルギーを超える可能性が出てくる。ただし，こ のブレークイーブン条件は, 科学的ブレークイーフ ンと称されるべきであって，加速器での電力などの 消費エネルギーや，核エネルギーから熱エネルギー へのエネルギー変換器でのロスが考慮されていな い。これらを考慮した，いわゆる経済的ブレークイ ーブンには,さらにもう3倍のエネルギー生産の向 上が必要であるといわれている。この 3 倍の壁を破 るために考えられていることを以下にまとめる。

（1）実験研究を $\mathrm{D}_{2} / \mathrm{T}_{2}$ 系の (温度, 密度, 混合比) について未探求の領域に進め, ょり有利な条件 を探る。

(2) これまでに考えられていない極端条件下での $\mu \mathrm{CF}$ を試みる。レーザ一,超強磁場, 高周波電磁 場, 局所的プラズマ,などの利用が考えられる。 特に，レーザーを用いて $(d t \mu)$ 分子生成をコン トロールしたり， $\alpha$ 付着率が小さくなるような 分子内核融合を起こさせる。

（3）実用炉で起こることが期待される高強度の $\mu^{-}$が，小さい領域に止められ $\mu \mathrm{CF}$ が起こる状 況では，ミュオン原子・分子同士が相互に影䉪 を及ぼ合うことが考えられる。このような系 では，此の減少など，エネルギー生産に有利な 現象が生まれる可能性がある。

(4) 加速器の効率向上, ミュオン発生技術の向上, 特に 1 次ビームの巡回利用などを追求し， $\mu^{-} 1$

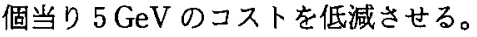

さてこれまでの $\mu \mathrm{CF}$ の実験から， $\mu^{-} 1$ 個当りの 100 回以上の核融合が起こっていることは確かであ る。この事実を踏まえて，より効率の良いエネルギ 一生産方式が考えられないであろうか。Petrovに よって提案されたミュオン核融合ハイブリッド炉 (MCHR)が一つの方式である(3)。この提案の重要な 点は, 加速器からの重陽子ビームから $\pi^{-}$生成と核 子生成を行わせ， $\pi^{-}$は $\mathrm{D}-\mathrm{T}$ 系の $\mu \mathrm{CF}$ ，核子は ${ }^{238} \mathrm{U}$ にあて核分裂と ${ }^{239} \mathrm{Pu}$ の生成を起こさせる。ま た $\mu \mathrm{CF}$ の結果生ずる $\mu^{-}$個当り 100 個の $14 \mathrm{MeV}$ 単色中性子の大半を ${ }^{238} \mathrm{U}$ にあて, 中性子 1 個当り 2.3 個の ${ }^{239} \mathrm{Pu}$ の生産と 0.86 回の核分裂に使用す る。これらの結果生ずる核分裂エネルギーを加速器 の運転に, ${ }^{239} \mathrm{Pu}$ を通常の原子炉の燃料に使抢うと いうものである。この考えでは， $\mu \mathrm{CF}$ のおかげで， 
加速器による核増殖効率が倍増し, すでに採算が取 れるとされている。しかしながらこの MCHR炉プ ラントでは，原子炉の持つすへての問題を内蔵する ことになり，核融合の持つメリットを幾分捨てるこ とになる。

いずれにせよ，もともと核融合を起こす領域が小 さいことが特徽の， $\mu \mathrm{CF}$ から強力に発生する単色 $14 \mathrm{MeV}$ 中性子は, 実用化の可能性があり, 早急に, 大型加速器に直結した実験ファシリティ計画の実現 が望まれる。

一方, $\mu \mathrm{CF}$ 現象の新しい応用として, 強力な熱, 严熱エネルギ一領域の中性子源とする考え方が提出 されている。この方式では， $\mu \mathrm{CF}$ 反応炉を液体 $\mathrm{D}_{2} \mathrm{O}$ で囲み, $\mu \mathrm{CF}$ 反応の結果生ずる $14 \mathrm{MeV}$ 中性子を減 速して低速中性子源とする。中性子源としての束強 度は $10^{11} / \mathrm{cm}^{2} ・ \mathrm{~s}$ 程度を確保することができる。高強 度陽子, 重陽子ビームを用いて中性子源を作る方法 としては，UやPbに直接ビームをあて中性子を多重 発生させる破砕中性子という考え方があり，RALISIS (英国), KEK-KENS(日本)等, 代表的な研究施 設が存在している。もし上記の評価が正しいならば， 加速器利用中性子源としての新しいブレークスルー となる。

また，現実にたやすく強力に起こっている核骶合 現象は，通常の熱核融合の工学的研究に奇与するほ か, $\mathrm{keV}$ 領域の低速 $\mu^{-}$源として基礎科学の発展に 寄与することも指摘されている(4)。

さて，常温核融合(正確には物質内低温核融合) は どうなったであろうか。1989 年春以来, 現在まで奏 験研究は継続されているが，必ずしも核融合現象を 直接的に示す決定的な結果が得られているとはいい がたい。最近の進展としては, 戸塚洋二(東大宇宙線 研)らによる神岡における実験がある。地下 $1 \mathrm{~km} の$ 位置に設置された水チェレンコフカウンタにより，
大立体角 $(20 \%)$ 低バックグラウンド $\left(10^{-4} / \mathrm{s}\right)$ で中 性子を測定できる測定系が用意され，これまでに positiveな核融合中性子を測定したと報告している Jones(ブリガムヤング大)，Menlove(ロスアラモス 国立研)，Wolf(テキサス農工大)などが, 次々と発生 源を持ち込んな゙。次の結果が得られている。

（1）電解法では，ランダム中性子発生は $10^{-4} n / \mathrm{s}$ のレベルで存在しない。Jones の結果(5) は再現 されない。しかしながら多重度 4 までのバース 卜状中性子発生が, $0.02 / \mathrm{h}$ の頻度で観測され， その原因は説明されていない。

（2）ガス加圧法では，ランダム発生は $10^{-4} n / \mathrm{s} の$ レベル以上では観測されず,多重度 20 もの大き な中性子発生を持つバーストは観測されなかっ た。Menloveの結果 ${ }^{(6)}$ は再現されていない。し かし, 多重度 3 までのバーストが $0.04 / \mathrm{h}$ の頻 度で観測された。この原因も説明されていない。 以上のように, 神岡での実験は, 1989 年にいわれ ていた $10^{-1} \sim 1 n / \mathrm{s} り 2$ 析以上下で,「何か」が起 こっていることを示している。これが低温核融合で あるかどうかは，今後の研究に待つ必要がある。

最近, Takahashiらは，パルス状電解によって， 再現性の良い常温核融合を発生させたと報告してい る(7)。発生する中性子は D-D 核融合より高いエネル ギーを持っていて，事実とするなら，現在の核物理 学ではとても理解できないものである。

\section{一參考文献一}

(1) PONOVAREv, L.I. : Contemporary Phys., 31, 219 (1990)

(2) BREUnliCH, W.H., et al. : Ann. Rev. Nucl. Sci., 39, 311 (1989).

(3) Petrov, Yu. V.: Nature, 285, 466 (1980).

(4) Nagamine, K. : Proc. Jpn. Academy, 65, 225 (1989).

(5) JONES, S.E., et al. : Nature, 338, 737 (1989).

(6) MENLOVE, H., et al.: To be published in Nature.

(7) TAKAHASHI, A., et al. : J. Nucl. Sci. Technol., 27, 663 (1990). 


\section{IX.おわりに}

財未末来工学研究所 神前康次

様々な核融合炉の将来展望について，それぞれの 専門家から解説して頂いた。現在中心プロジェクト となっているトカマク型において, 炉概念の構築に 向けて大きな努力が払われていること，また他の方 式についても，最近大きな進展を見せ，次の段階へ の進め方が差し迫った課題となっているものがある ことが示されている。これらの核融合エネルギーシ ステムを一望することは，それそれれの方式の抱えて いる課題とその共通点, 差異を明確にし, 全体とし ての研究開発の進め方を検討するためにも役立つと 考えられる。

ここでは最後のまとめとして，これらの個々の核 融合炉概念をべースとして，全体として核融合エネ ルギーがどのような可能性を持っているかについ て，まず私見を交えながら概観したい。次いで，各 方式の課題と今後の開発の進め方についてまとめる こととする。

\section{1. 核融合エネルギーの可能性}

おそらく「本特集」の様々な核融合炉の概念をご覧 になった読者の方々は, 本当にこれらの概念が物理 的, 技術的に成立するのかという疑問とともに, それ が成立したとしてエネルギー源として魅力的なもの かどうかを知りたくなるのではないかと思われる。 実際「本特集」をまとめる過程においても多くの方か ら，このような核融合の持っている潜在的可能性を 抽象的にではなく，実際の炉概念の検討をべースに してラフにではあっても定量的にまとめられないも のかといわれた。

以上紹介した炉概念の中で，著者はいくつかの炉 設計について，炉全体のシステム設計あるいは経闵 性の作業に密接に係わり, 横断的な比較を行う機会 を持つことができた。そこで核融合エネルギーの可 能性について，単刀直入な質問に答える形で全体像 についてまとめたい。

（1）核融合炉はエネルギ一収支が プラスとなるか

この疑問に対してはここで紹介した核融合炉の概 念設計については, プラントが仕様通りに運転でき
る限り充分にエネルギー収支はプラスであるといえ る(根拠となる物量比較は後述)。

\section{（2）核蠤合炉は経済的に蛙力的か}

核融合炉のみならず，新型原子炉や太晹発電等新 エネルギー技術の経済性の評価については不信感が 多い。実際, 開発当初の楽観的な経済性評価が, 開 発の最終段階で大幅に修正され，技術開発に成功し ても経済性が成立せず実用化できない例は数多くあ る。経済性の評価の基本は，海外等の都合の良い文 献を引用するのではなく,プラントの設計図であり， それに基づく物量をべースとしたコスト積上げであ る。

本章ではその物量について概算値の比較を第 $\mathbf{X}$ $1, \mathrm{XX}-2$ 表にまとめる。表に示すように，トカマク 型核融合炉の炬本体は $2 \sim 4$ 万 $\mathrm{t} て ゙ あ り ，$ 軽水炉の 炉本体より 1 桁以上多く, 軽水炉の原子炉系と比較

第DX-1 表 各種発電プラントの同出力当り物量の比較 $(100$ 万 $\mathrm{kW} ， 70 \%$ 設㣁利用率換算 $1,000 \mathrm{t})$

\begin{tabular}{lccccc}
\hline & $\begin{array}{c}\text { ト力又 } \\
\text { ク型炻 }\end{array}$ 軽水炉 & 火力 & 風力 & 太陽光 \\
\hline 炉本体・炉冷却系 & $30 \sim 40$ & $\sim 10$ & 10 & - & - \\
プラント合 計 & $50 \sim 70$ & $30 \sim 40$ & 40 & $\sim 500$ & $\sim 1,000$ \\
\hline
\end{tabular}

第IX-2 表 各種核融合発電プラントの物量比較 $(100$ 万 $\mathrm{kW}$ 当り，単位 $1,000 \mathrm{t})$

\begin{tabular}{|c|c|c|c|c|}
\hline & $\begin{array}{l}\text { トカマク } \\
\text { 型核融合 } \\
\text { 快作 }^{+1}\end{array}$ & 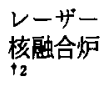 & $\begin{array}{l}\mathrm{D}-{ }^{-3} \mathrm{HeFRC} \\
\text { 核融合炉 } \\
\mathbf{t}^{3}\end{array}$ & 軽水炉 \\
\hline 炉本体 & $20 \sim 30$ & 5 & 5 & 1 \\
\hline $\begin{array}{l}\text { 炉冷却系・レー } \\
\text { ザー等 }\end{array}$ & 10 & $15 \sim 25$ & $5 \sim 10$ & $\sim 10$ \\
\hline $\begin{array}{l}\text { タービン等周辺 } \\
\text { 設備 }\end{array}$ & $20 \sim 30$ & $20 \sim 30$ & $10 \sim 15$ & $20 \sim 30$ \\
\hline $\begin{array}{l}\text { 発電プラント } \\
\text { 合計 }\end{array}$ & $50 \sim 70$ & $40 \sim 60$ & $20 \sim 30$ & $30 \sim 40$ \\
\hline
\end{tabular}

†1トカマク型炉本体については,マグネット,炉棈造が积 上げの中心である。また周辺設備は軽水炬と同じとし ている。

† 2 レーザー核蛆合発電プラントは, $4 \mathrm{MJ}$ の半導体励起固 体レーザーにより，4つの炉キャビティを㗨娌するモ ジュラープラントを想定している。このため共用する レーザーの物量の負担が小さくなるが，精度の高い稓 上げは末だ行われていない。

† $3 \mathrm{D}^{-3} \mathrm{He}$ 核融合炉では，荷電粒子による直接発䉓のため プラント奻率が約 $60 \%$ と, 同西気出力当りの就出力が 通常のプラントの約 $1 / 2$ でる。このため物韋り全体 に少なくなっている。 
しても数倍の重量である。しかし，風力発電や太陽 光発電のプラント重量と比較すると 1 桁以上コンパ クトである。

再生可能エネルギーの同出力当りのプラント物量 が大きいのは，基本的にはエネルギー密度の低さと 設備利用率の低さにある。現在地球環境問題で自然 エネルギーの利用が強調されているが，ここに示す プラント重量(アモルファスシリコン等開発目標と している改良型のもの)の例でも，そのプラント建設 に投入されるエネルギーを回収するのに $1 \sim 2$ 年必 要と評価されている。なお現在の単結晶 $\mathrm{Si}$ を用いる 太陽光発電では，そのプラント建設への投入エネル ギーの回収に 10 年かかるとの評価もあり，その普及 は $\mathrm{CO}_{2}$ 排出量の一時的増大につながりかねない。

以上の物量の検討に加えて, 物量当りの単価の違 いを考虑してコストを積上げると横並びのコスト比 較ができる。この詳細は省略するが, 最も炉概念が 具体化されているDTトカマク炉は, 軽水炉に比較 して数倍の建設費となる可能性があるものの, 再生 可能エホルギーに比較しては低コストになることが 期待される。ただし，第I章“はじめに”で述べた 課題を克服して，材料の寿命やプラント保守の問題 をクリアーすることが不可欠である。

核融合炬に関する相互比較については，レーザー 核融合炉は，レーザーが高価であり，そのコストが 建設費の半分以上を占めるといわれてきた。ここで 対象としているモジュラー型プラントは, レーザー の絽返し率の上限値と炬キャビティでのペレット爆 縮の絽返し率の制約の差に着目して，プラント全体 システムの最適化を図ったものである。このレーザ ーシステムの効率的な共用が可能となれば，レーザ ーコストの負担は格段に低くなる。この場合, 米国 等で主張されているイオンビーム等の低コストのド ライパーの開発を待たないで, 既存の固体レーザー 技術の延長でも充分経済的に魅力的となる可能性が ある。レーザー炉はミ二水爆の高繰返しを高度に制 御する必要があり, 従来の発電プラントの一般的概 念とは非常に異質なものである。説得力のある炉の 概念設計が重要課題である。

D-3 He FRC 核融合炉は，その出力の大半を占め る荷電粒子を直接発電に使え, また DT 中性子によ る問題が根本的に解決する等, 理想的な発電プラン 卜となる可能性がある。この特徵により，同電気出 カ当りの熱出力が通常の発電プラントのほほ $1 / 2$ に
なる等により,プラントの重量, 建設費の大幅な低減 が期待できる。ただし，この㚸概念の物理的基礎の 実証が必要である。

\section{（3）核融合は無尽蔵の資源か}

DT 核融合についてはLi 資源の量が問題となる が，低品位のものを含めると資源量は充分多く，Li 資源が DT 炉の制約になるとは考えにくい。 $\mathrm{D}^{-3} \mathrm{He}$ 核融合では, ${ }^{3} \mathrm{He}$ は地上にはほとんど存在しないの で，月面のレゴリスに吸着されている太陽風起源の ものを採取するか，木星や海王星等の大気中に含ま れる ${ }^{3} \mathrm{He}$ を利用する必要がある。前者の場合, ${ }^{3} \mathrm{He} の$ 濃度が低いので, ${ }^{3} \mathrm{He} 1 \mathrm{~kg}$ の採取には約 10 万 $\mathrm{t} の$ 月の表土を処理する必要があり，その経済性の評価 が課題となっている。

後者の海王星等の外惑星の ${ }^{3} \mathrm{He} の$ 利用は, その往 復に長期間を要するので，無人の資源採取船を開発 する必要があるが, 長期的には充分可能性があり, 無尽蔵のエネルギー源と考えてよいであろう。

\section{（4）核融合は地球環境を救うか}

この答えはイエスである。少なくともエネルギー 利用の点から, $\mathrm{CO}_{2}$ 排出量を削減するために長期的 に最も有力な手段になると考えられる。その理由は， 再生可能エネルギーの現実的な利用量の拡大の制 約，および原子力発電の立地制約等による世界的な 大幅な利用拡大の制約による。つまり現在省エネル ギー以外に決定的に有効な手段がないことによる。

ところが現在地球環境保全のため, 核融合開発が 不可久との期待はあまり聞かれない。一般の人々に とって核融合は極限技術を追求する蓦であり，現実 的な問題解決につながるところまで進歩してきてい るとは考えられていないことによるのかもしれな い。このためにも多様な可能性を持つ核融合の将来 展望を示し，そのヴィジョンのもとにエネルギー開 発として, 次段階の核融合研究開発を進めることの 意義を明確にしていくことが重要である。

\section{2. 今後の開発の進め方}

\section{（1）トカマク型核融合炉}

現在大規模にプロジェクトが進められているトカ マク型炉は，ITER の建設により動力炉級のトカマ ク型炉心を実証することが中心課題である。また今 まで開発してきた技術を結集して，炬工学技術をイ ンテグレートするものとしても大きな意味を持つと 考えられている。特に魅力的なエネルギー源への将 
来展望という観点からは, 動力炉の概念設計研究と ITER あるいは国内次期装置の設計研究との有機的 な連携を図ることが不可欠である。

\section{（2）へリカル型核融合炉}

ヘリカル型炉の開発の進め方については，すでに 第 III章で炉設計研究と R\&D との関係について様々 に述べられているが，特に現在建設が進められてい る大型ヘリカル実験装置での実験内容をより具体化 し，その先の段階への発展性を示していくことが重 要な課題と考えられる。

\section{(3) D-3 He FRC 核融合炉}

本炬概念では，高エネルギー中性粒子ビームの入 射と核融合反応陽子により，FRCプラズマが安定化 され，また電流を維持し定常化することを基本原理 としている。この基本原理は, プラズマの安定化や 定常化のための制御手段を持たない従来の FRC 方 式のイメージを根底から変えるものである。この原 理実証実験が最大の緊急を要する課題である。また このことは，従来の MHD 的なプラズマの物理像に 対し，高エネルギー粒子が主要な役割りを果たすプ ラズマ物理の発展につながっていく可能性がある。 核融合理工学におけるパラダイムチェンジといえる ようになるのかもしれない。

\section{（4）慣性核融合炉}

レーザー核融合炉は近年，核融合炉に必要なハイ ゲインのペレット爆縮物理の見通しを確実にし，ま た炉で用い得る高効率, 高絽返し率の大出力レーザ 一の開発見通しが確かなものとなってきた。この最 大のクリティカルな課題に対し, 大きなブレークス ルーがあったことは未だ十分認識されていないよう である。多分レーザー核融合炉研究開発の置かれて いる現状ほど，現実と一般の人々の認識(期待)との 間のギャップが大きいことは珍しいと考えられる。 次段階のエネルギー開発へ向けた開発計画の具体化 と，新たな開発体制を作るための準備が必要な時期 にあるといえよう。

（5）核融合・核分裂ハイブリッド炉

DT 核融合炉は中性子が出力の $80 \%$ を占め, 中性 子炉といえるものである。その中性子を単に熱とし て利用するのではなく，核燃料堌殖等の核変換にも
用いることは原理的に優れた可能性を持つものであ る。最近の世界の核不抎散政策の動向や核分裂燃料 への需要の変化により，ハイブリッド炉の開発の位 置づけは影響を受けるものではあるが，この炉型の 設計研究あるいはシステムの研究は重要課題の 1 つ である。

（6）核融合ロケット

第VII章では核融合の興味ある応用の一つとして, 核融合ロケットの設計例が示されている。より具体 的な設計㭘討により，総合的なフィージビリティが 示され，発電炉開発との関係等が明確になることが 期待される。

（7）ミュオン触媒核融合および常温核融合

第V章では，低温核融合という意味で最近の物質 内の常温核融合の先輩格であるミュオン触媒核融合 と常温核融合のレビューが行われている。「本特集」 は将来のエネルギーシステムとしての展望を狙いと しているが，ミュオン核融合はさておき，常温核融 合については，むしろ物質内での未知の新しい現象 の探索の科学研究として位置づけることが必要と思 われる。このような新領域の研究における科学精神, 批判精神の重要性については，初期の核融合プラス マ研究の歴史でも示された通りである。

\section{（8）開発の進め方のまとめ}

以上示されたように，核融合研究開発は，具体的 な核融合炉の開発に向けて，その実現のためのクリ ティカルイシューを明確にしながら大きく前進しよ うとしている段階にある。その開発は直線的なもの でなく,多くの技術開発の歴史が示しているように, 将来発展性のある技術が様々な可能性の中から選択 され，淘汰されていくプロセスと考えられる。この ような開発を限られた予算の中で進めるためには， 明確な目標を指向した中心的プロジェクトに重点的 に予算配分を行うこと，および発展性のある小規模 プロジェクトやリサーチに適正な予算配分を行うバ ランシングの考え方が不可欠である。今後，科学技 術庁, 文部省等の行政当局においては今までの延長 上で硬直的に予算配分を行うのでなく，適正な予算 配分の基本ポリシーを確立していくことが強く望ま れるところである。 